Florida International University

FIU Digital Commons

10-23-2004

\title{
An examination of Bernard Connor's The History of Poland (1698) and its depiction of the political, religious, and cultural history of the Polish- Lithuanian commonwealth
}

John Paul Bardunias

Florida International University

DOI: $10.25148 /$ etd.FI14050429

Follow this and additional works at: https://digitalcommons.fiu.edu/etd

Part of the History Commons

\section{Recommended Citation}

Bardunias, John Paul, "An examination of Bernard Connor's The History of Poland (1698) and its depiction of the political, religious, and cultural history of the Polish-Lithuanian commonwealth" (2004). FIU Electronic Theses and Dissertations. 1397.

https://digitalcommons.fiu.edu/etd/1397 
FLORIDA INTERNATIONAL UNIVERSITY

Miami, Florida

AN EXAMINATION OF BERNARD CONNOR'S THE HISTORY OF POLAND (1698)

AND ITS DEPICTION OF

THE POLITICAL, RELIGIOUS, AND CULTURAL HISTORY OF THE POLISH-

LITHUANIAN COMMONWEALTH

A thesis submitted in partial fulfillment of the

requirements for the degree of

MASTER OF ARTS

in

HISTORY

by

John Paul Bardunias

2004 
To: Dean R. Bruce Dunlap

College of Arts and Sciences

This thesis, by John Paul Bardunias, and entitled An Examination of Bernard Connor's The History of Poland (1698) and its depiction of the Political, Religious, and Cultural History of the Polish-Lithuanian Commonwealth, having been approved in respect to style and intellectual content, is referred to you for judgment.

We have read this thesis and recommend that it be approved.

Rebecca Friedman

Lara Kriegel

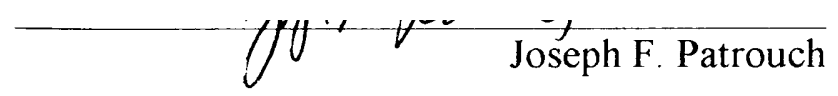

Date of Defense: November 23, 2004

The thesis of John Paul Bardunias is approved.
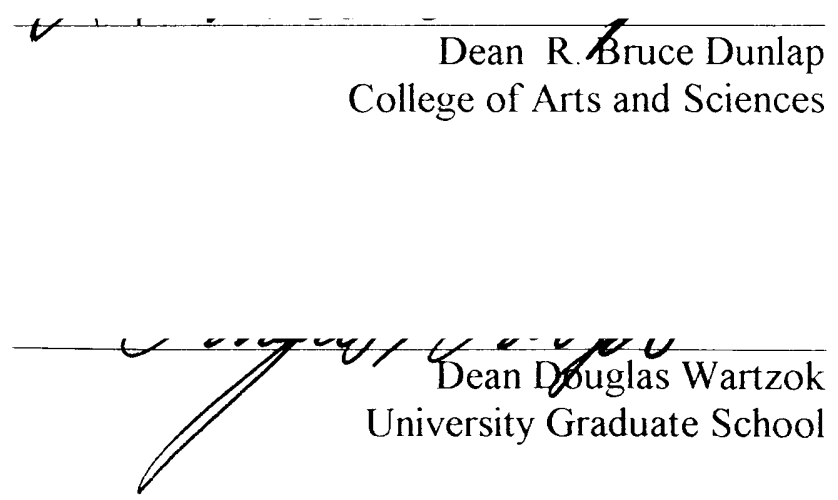

Florida International University, 2004 


\section{DEDICATION}

This thesis is dedicated to my father and mother, Peter and Bonnie Bardunias,

who kept our family together through troubled times and loved me no matter what I did with my life. If our rewards are in the next life, may they enjoy holding hands in heaven and sharing scenes of beauty of which we mortals can only dream. 


\section{ACKNOWLEDGMENTS}

I would like to thank all of my family for helping to support me during the writing of my thesis. I wish to specifically thank my grandmother, Florence Mauro, my grandparents, Henry and Helen Posluszny, my brothers, Peter and Paul, my aunt, Paulette Merchel, and my aunt and uncle, Joseph and Sophie Strazewski, for their encouragement and support through the confusing times that plagued me during my stay in Miami after the death of my beloved father and mother. I would also like to thank my sister-in-laws Eileen and Helaina for their help in keeping me sane. I would like to thank my girlfriend Andrea Vasta for proofreading my drafts and giving me solace in times of despair. I would also be remiss if I did not thank my niece, Arianna, and nephew, Jonathan, for being a needed distraction during stressful moments in my life.

I also wish to thank my committee members, Professors Joseph F. Patrouch, Lara Kriegel and Rebecca Friedman, who have been patient, guiding and supportive of me during the writing of this thesis. These professors have helped to urge me on in my task, while keeping me from flying off into romantic visions of the Commonwealth. Each of them has opened my mind to new perspectives on history. When it is all said and done, I will miss the times I was able to talk to them and receive feedback about my ideas on Poland and central Europe. They are all amazing professors and valuable assets to the department.

In closing, I would also like to thank the secretaries in the FIU History department for making me laugh and pumping me full of Cuban coffee. Finally, thanks to Professor Peterson and Mrs. Vera Simm for helping me learn German. Thanks to all those who I have not mentioned who were also there for me either in my personal life or graduate 
studies. To name everyone who has helped me would take pages. Thank you all for your understanding and support. 


\begin{abstract}
OF THE THESIS
AN EXAMINATION OF BERNARD CONNOR'S THE HISTORY OF POLAND (1698)

AND ITS DEPICTION OF

THE POLITICAL, RELIGIOUS, AND CULTURAL HISTORY OF THE POLISH-

LITHUANIAN COMMONWEALTH
\end{abstract}

by

John Paul Bardunias

Florida International University, 2004

Miami, Florida

Professor Joseph F. Patrouch, Major Professor

Connor was an Irish-born member of seventeenth-century English medical society who made an impact on medicine through his use of anatomy. This forward-thinking scientist also worked as a court physician for the Polish king John III Sobieski (16291696) and published a history of that country.

This thesis will examine Bernard Connor's 1698 publication The History of Poland to show that the Commonwealth was considered a vision of a progressive European parliamentary government that could serve as a model for a struggling English parliamentary government, thus supporting Larry Wolff and Maria Todorova's vision of the later eighteenth-century creation of the idea of a backward "eastern Europe." 
Chapter I. Introduction.

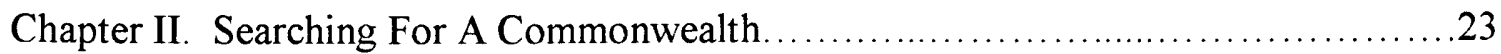

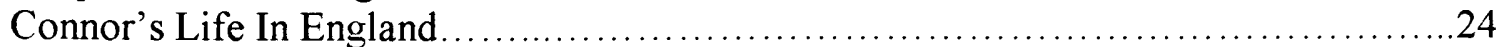

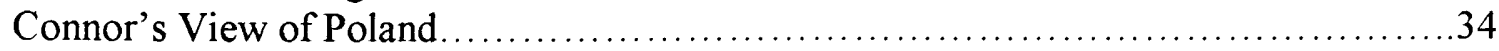

Poland in the European Context............................................... 44

Similarities Between Cossacks and the Irish and Scots ............................ 47

The Polish-Lithuanian Commonwealth as the Continental England....................48

Chapter III. The Polish-Lithuanian Commonwealth................................ 55

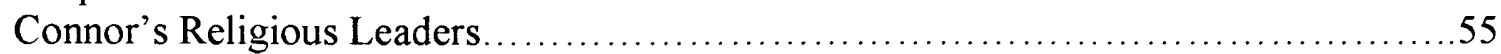

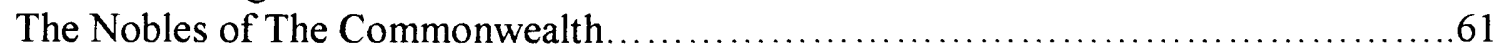

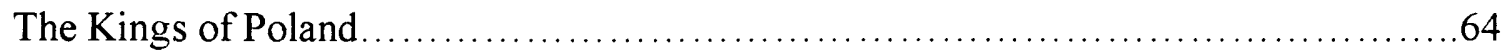

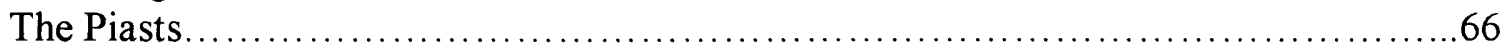

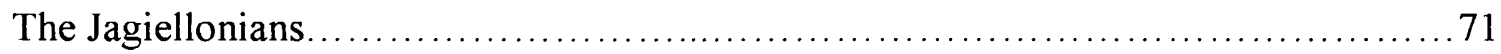

The Elected Dynasties .................................................... 77

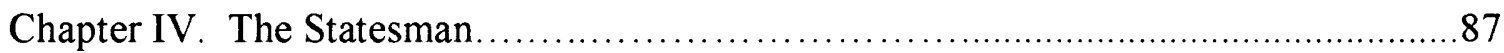

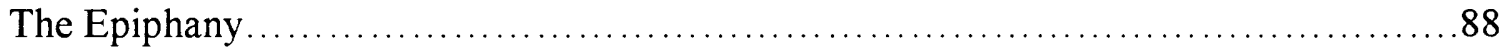

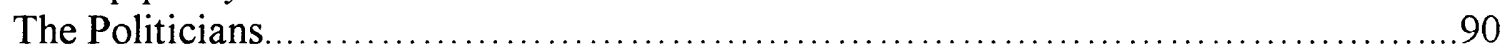

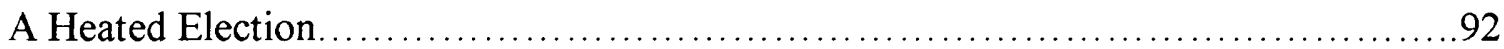

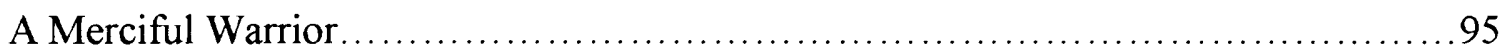

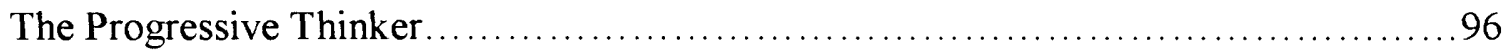

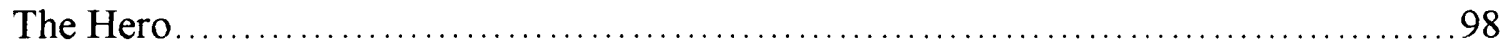

A "German" Elector On The Throne........................................... 101

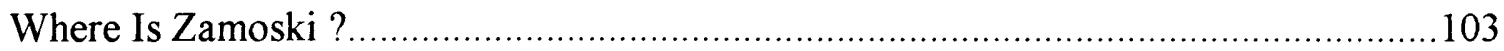

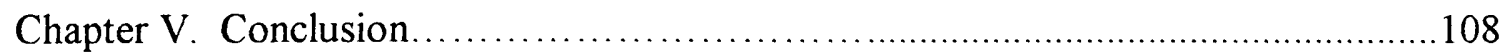

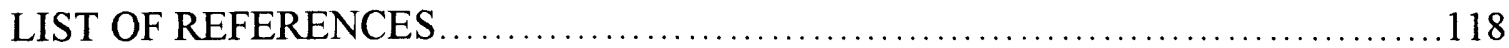


The Irish physician Bernard Connor, who lived from 1666 till 1698, hoped the Polish-Lithuanian Commonwealth would continue to fight against European despotism after his death. He never saw the Commonwealth disappear from the political map of Europe after being partitioned by Prussia, Russia and Austria in 1795. The image of the Commonwealth that Connor described in his 1698 publication The History of Poland was never adjusted to the problems Poland faced in the eighteenth century. Connor never saw the Commonwealth undergo its three partitions and subsequently slip into the obscurity of the newly-forming picture of a Europe divided between eastern and western spheres of influence. Connor's history is a picture of Poland's return to political importance after the turbulent years of the mid-seventeenth century. To Connor, the Commonwealth that he beheld was an example to other parliamentary governments. It showed that a kingdom could be decentralized and tolerant while continuing to be a strong force in European politics.

Connor grew to importance due to his use of human anatomy in order to treat sicknesses. His belief in using the study of anatomy and the scientific method to understand the universe would often create friction with those above him. His attempt to find scientific explanations for the mysteries behind Christ's miracles almost ended in his arrest for attempting to undermine the Church of England. ${ }^{1}$ Connor was pardoned only after he wrote a letter of apology to the king explaining that he was merely trying to

1 Davis Coakley, Irish Masters of Medicine (Dublin: Town House, 1992), 23-24. 
defend the Anglican religion against those who might otherwise mock it. ${ }^{2}$ Nevertheless, as a member of the seventeenth-century British intelligentsia, he was no stranger to the struggles within England between the kings and the Parliament. Connor had first-hand experience with the problems of parliamentary government in a time where centralized authority was expanding. He knew about the governments of James I (1603-1625), Charles I (1625-1649), Oliver Cromwell (1649-1658), Charles II (1660-1685) and experienced the constant warfare between James II (1685-1688) and William of Orange (1689-1702). Born into the Kerry branch of the O'Connor family, Connor knew what it was like to be one of those petty nobility who were excluded from a role in English government until they conformed to the desires of the ruling elites. He left the Catholic religion of his birth, converted to Anglicanism, and altered his name in order to be allowed to practice medicine in England. ${ }^{3}$

Through his studies in Paris, Connor met the children of a Polish ambassador to France and journeyed with them to Poland where he was not only allowed to discuss his beliefs in medicine, but was appointed the king's personal physician. ${ }^{4}$ Under the rule of the Polish king John III Sobieski (1674 to 1698), Connor was exposed to a kingdom that ruled the peasants with an iron fist, but allowed all members of religious and ethnic groups into the greater nobility (the magnates) and the lesser nobility (szlachta). These

\footnotetext{
2 Bernard Connor. A Copy of a Letter Sent His Grace *** From Dr. Connor, Member of the College of Physicians and Roval-Society, Concerning His Medicina Arcana de Mystico Corporis Mumani Statie: or A Latin Treatise, In Which IIe Designs to Explain the Miracles Relating to IIuman Bodies, hy the Prinicples of Physice (London: For Sam Briscoe. 1696), 1.

${ }^{3}$ Coakley, Irish Masters of Medicine, 19-20.

${ }^{4}$ W. F. Reddaway, J. H. Penson. O. Halecki, and R. Dyboski. The Cambridge Ilistory of Poland: From the Origins to Sobieski (to 1696). London: Cambridge University Pres, 1950. Reprint (New York: Octagon Books, 1971), 578.
} 
nobles would gather after every king's reign and vote to elect another leader. This leader would be forced to swear allegiance to a political body that held the right to depose him if he did not uphold the interests of the Senate. ${ }^{5}$ The young Irish physician observed a government run by an upper house called the Sejm that voted on matters of state and international politics and a lower house called the Sejmiki that voted on matters of provincial issues. These houses were run by all forms of nobles and high officials within the state and city bureaucracy. ${ }^{6}$ Connor states in his preface that he wished to write The History of Poland in order to give his English speakers a better understanding of the kingdom in which he had lived for three years. Connor hoped that Poland's free parliament could act as a model for English politics.' He gave the reader an introduction into what concepts he wished to prove within his book. He broke his history into chapters and enforced his opinions within these chapters through the documentation of other sources in his bibliography. He gave his readers a scientific model based on research and observation. This model was intended for his readers to analyze and reproduce in England.

Connor's The History of Poland is divided into two volumes. The two volumes were edited by the Anglican preacher and thinker, John Savage (1673-1747). Savage acts as an editor in volume one, only expanding his position in the last chapters on geography. Connor wrote, “...I neither could take any Delight, nor have any Leisure to write over, or

\footnotetext{
5 Daniel Stone. The Polish-Lithuanian State, 1386-1795 (Scattle: University of Washington Press. 2001). 119.

${ }^{6}$ Stone. The Polish-Lithuanian State, 120.

Connor. The History of Poland, v.
} 
to put into due method the Memoirs I brought from Poland: so that the Publick is indebted to my ingenious Friend Mr. Savage; for without his help this Account of Poland could not doubtless have thus appear'd these several years." ${ }^{\circledR}$ Savage, however, does not have a major impact on the first volume. From the Preface on the themes within the book seem to be Connor's interpretation of Polish history. Connor's preface gives the reader an introduction into what concepts he wishes to prove within his book.

The author urges other English speakers to visit and write more extensive histories about the kingdom of the Poles. ${ }^{9}$ Although Connor mentions how he wanted to be "...the first that has given any History of that Country in our [English] Language....," the book is actually a model to help guide English politics. Connor also wished to satisfy the English public's curiosity about the new royal election in Poland by giving his readers some information about the politics and social upheavals behind the election of the latest king. He perceived this election to be an unprecedented moment in Polish history. Connor believed that it was the first time a German had been elected to the Polish throne. However, this was also an example of Connor's attempt at giving England guidance. His use of King August's election was attempt to warn England about the problems of a "German" king.

The history highlighted the political checks and balances as well as the character of the people who fought for, ran, and ruled the Commonwealth. The book is organized in such a way that it attempts to give the reader a better understanding of the

\footnotetext{
$\times$ Connor. The History of Poland, iv.

${ }^{9}$ Connor, The History of Poland, $\mathrm{v}$.

11) Connor. The History of Poland, iv'.
} 
Commonwealth's history in order to demonstrate how it represented a powerful parliamentary government with an elective kingship. The history creates this vision of the parliamentary European power through its preface and the accounts of religious, civic and royal figures that represent problems faced in Poland. These characters are used to demonstrate the powers in the parliamentary kingdom that both help to propel Poland into a place of political dominance and impede the Commonwealth's growth. In so doing Connor also gives the English reader a series of models to use in order to better evaluate the actions of King Sobieski. This model of Sobieski and those Polish figures that help to define his character are in turn used to emphasize those character traits that can be found within English political figures that may have a positive or negative affect on England's parliamentary growth.

These character traits are emphasized in his depictions of Stanislaus Zaremba, Bishop of Kiovia ${ }^{11}$, the noble, John Zamoyski (1542-1605) ${ }^{12}$, the kings Boleslaus the Wry- Mouth (1107-1138) $)^{13}$, Casimir III the Great (1333-1370) ${ }^{14}$, Casimir IV Jagiello $(1447-1492)^{15}$, Sigismund August Jagiello (1548-1572) $)^{16}$ and Stephen Batori (1576-

\footnotetext{
11 Bernard Connor. The History of Poland: in several letters to persons of quality, giving an account of the antient and present state of the kingdom, historical, geographical, physical, political and ecclesiastical... : with sculptures, and a new map after the best geographers: with several letters relating to phwsick. vol. 1. Editor John Savage (London: Printed by J.D, 1698), 125-128.

12 Connor, The History of Poland, 102-113.

13 Connor. The History of Poland, 31-33.

14 Connor, The History of Poland, 54-56.

15 Connor. The History of Poland, 63-66.

16 Connor. The History of Poland, 69-83.
} 
1586). ${ }^{17}$ are there to emphasize the greatness of Sobieski's climb to power. The noble Christopher Zborowski ${ }^{18}$ and the Vasa kings, Sigismund (1587-1632) ${ }^{19}$, Vladyslaw(1632$1648)^{2 n}$ and Casimir(1674-1668) $)^{21}$ who are the Polish embodiment of the weakness in Sobieski and the English Stuart Dynasty. The heroic and villainous nobility and clergy dramatize the power politics faced by both kingdoms. In Connor's history, the reader is not only learning the history of the Polish-Lithuanian Commonwealth but also getting a chance to understand why it was important for a kingdom to create a decentralized political system that was tolerant of religion and ethnic minorities.

Connor's analysis of the Commonwealth's liberal politics is, notably, often minimized by those who have written biographies of the talented Irish physician. The kingdom that Connor praised is often reduced to stereotypes and pagan rituals by historians such as Baruch S. Blumberg and Jean L. Blumberg. In their article, "Bernard Connor (1666-1698): and His Contribution to the Pathology of Ankylosing Sodalities" they summarize The History of Poland, emphasizing the use of words such as "different" or "unique" in order to make Poland a distant and wild place. ${ }^{22}$ If the sections of the history that praise Poland's parliamentary history and liberal thinking are ignored there is

17 Connor., The History of Poland, 87-101.

18 Connor, The IIistory of Poland, 88-90 and 102-111.

19 Connor. The IIistory of Poland, 111-115.

21. Connor, The History of Poland, 115-118.

21 Connor, The History of Poland, 118-140.

22 Baruch S. Blumberg and Jean L. Blumberg. "Bernard Connor (1666-1698): and His Contribution to the Pathology of Ankylosing Sodalities," Journal of the History of Medicine and Allied Sciences. vol. 13 (New York: H. Shuman, 1958), 349-366, 353. 
a focus on the rituals of pagan Poles and Lithuanians within Connor's book that could be emphasized in order to give the reader a view of the wild Poland..$^{23}$

Perhaps one of the reasons for this emphasis on Poland's differences had to do with the tendency to rewrite Polish history after its decline. Already by the eighteenth century, Voltaire's 1728 publication The Lion of the North about the conquests of the Swedish king, Charles XII (1697-1718) began to foster a negative view of the Polish parliamentary system. ${ }^{24}$ This negative image may have been due in part to the problems the Commonwealth faced in the eighteenth century, combined with the changing understanding of what constituted a modern political system. The Lion of the North echoes many of Connor's descriptions of the Polish Commonwealth. However, Voltaire does not give the Commonwealth the same place of honor that Connor did. It is now a throwback to a time before the great despots of Europe began to rise.

While Connor's The History of Poland praised the way the Commonwealth resisted the despotic powers in Europe, Voltaire, like other writers of the eighteenth and nineteenth centuries, began to condemn the Commonwealth for its lack of central authority. Voltaire writes, "[a] nyone who saw a king of Poland in all his regal and majestic pomp might think him the most absolute ruler in Europe; he is, however, the least absolute...[t] he king of Poland at his very coronation... dispenses his subjects from the oath of obedience, should he violate the laws of the Republic." ${ }^{25}$ In contrast Voltaire's

\footnotetext{
23 Blumberg, "Bernard Connor (1666-1698)." 352.

24 Voltaire, Lion of the North: Charles XII of Sweden. Translator, M.F. O. Jenkins (New Jersey: Associated University Presses, 1981), 59-61.

${ }^{25}$ Voltaire, Lion of the North, 60.
} 
1733 publication Letters Concerning the English Nation applauds the English Parliament for its ability to keep England from becoming despotic. He explains "[t] he English are the only people upon earth who have been able to prescribe limits to the power of Kings by resisting them; and who, by a series of struggles, have at last establish'd that wise government...." ${ }^{" 26}$ This could mean he had a change of heart or he demonstrates a strong bias against Poland for being part of those territories that many eighteenth-century philosophers labeled eastern Europe.

Larry Wolff's Inventing Eastern Europe and Maria Todorova's Imagining the Balkans attempt to shed light on this vision of a Europe divided into a western civilized world, and a eastern, uncivilized one by studying the history of the creation of a "western" Europe and "the concept of a eastern" Europe. ${ }^{27}$ Wolff focuses on the eighteenth-century philosophers' creation of a backward Eastern Europe in order to support the Enlightenment's vision of a proud and civilized western Europe dominated by Germany, France, and England. Wolff specifically looks at French and English attempts to assert their own pedigree to high civilization over the shifting politics of the Mediterranean world. In his conclusion Wolff explains that, “ ...Eastern Europe appears in this book as an intellectual object under construction--entered, possessed, imagined, mapped, addressed, and peopled--then the active subject may be identified from the sources, the travelers and philosophers of the Enlightenment... under construction, by its

\footnotetext{
26 Voltaire. Letters Concerning the English Vation. Editor and Translator. Nicholas Cronk (New York: Oxford University Press, 1999), 34.

2- Maria Todorova, Imagining the Balkans (New York: Oxford University Press 1997) and Larry Wolff. Inventing Eastern Europe: The Mapping of Civilization on the Mind of the Enlightenment (Stanford:

Stanford University Press, 1994) both focus on the use the way Enlightened thinkers began a trend towards alienating those Europeans that lived east of the German borders.
} 
own hand and pen, inasmuch as inventing Eastern Europe was inseparably dependent upon the reciprocal process of inventing Western Europe." in a western-dominated historiography, western philosophers and historians chose to rationalize their greatness by labeling eastern Europe an older more archaic Europe. This included the creation of a fantasy world that was imposed upon cultures and histories in order to satisfy the western Enlightenment's notions of superiority and civilization.

According to Wolff, Voltaire was one of the first philosophers to begin this trend towards a divided "western" and "eastern" Europe. ${ }^{29}$ Wolff writes, "[1] ike so many other great ideas in the age of Enlightenment, that of Eastern Europe may be said to have begun with Voltaire." ${ }^{30}$ Voltaire was a supporter of both the Russian Tsar Peter III (1728-1762) and Tsarina Catherine II the Great (1729-1796) as well as the Swedish king Charles XII. In order to turn the Russian rulers into Enlightened despots and Charles XII into the Lion of the North who would bring civilization to a chaotic and uncivilized world, Voltaire chose to alter what was considered "northern" Europe and "southern" Europe. Wolff explains that "[s] uch a method, when it came to designating geographical spaces, demanded of Voltaire a mental rearrangement of the map of Europe, a table of relations that replaced the north-south axis with an east-west axis." ${ }^{31}$ According to Wolff, Voltaire "... brought into alignment the land that tempted foreign armies and native brigands, lands that awaited discovery by adventurous travelers and far-away

\footnotetext{
28 Wolff, Inventing Eastern Europe, 360.

29 Wolff, Inventing Eastern Europe, 157.

30) Wolff, Inventing Eastern Europe, 89.

31 Wolff, Inventing Eastern Europe, 92.
} 
philosophers. The alignment made sense from the French perspective, because these lands appeared as related in backwardness." 32 This desire for a European realignment is important to Wolff's book because like Voltaire many of these Enlightened writers never traveled farther than the borders of the Holy Roman Empire.

Those who did travel further went searching for examples of the backward or odd. ${ }^{33}$ This image of the fantasy Europe was also promoted through fiction. Wolff explains that "Eastern" Europe was most fully revealed as a realm of fantasy in The Travels and Surprising Adventures of Baron Munchausen, by Rudolf Erich Raspe."34 These fictitious accounts helped to promote the Enlightenment's vision of the fantastic east that lie beyond the borders of the Holy Roman Empire. In The Travels and Surprising Adventures of Baron Munchausen Poland is the end of Europe. It is the doorway to the world of fantasy. ${ }^{35}$ Raspe turns Poland to a middle ground between the east and west.

Although Todorova's main focus is on the creation of an image of the Balkans and their confused place in European politics throughout the early modern and modern eras, she uses a eastern Europe/Orient formula in her depiction of the evolution of this image. She spends two chapters discussing the Balkans' continual shift between Europe, Eastern Europe and the Orient. Todorova writes, "[a] s in the case of the Orient, the Balkans have served as a repository of negative characteristics against which a positive

\footnotetext{
32 Wolff. Imenting Eastern Europe, 92.

33 Wolff, Inventing Eastern Europe, 90.

34 Wolff, Inventing Eastern Europe, 100.

35 Wolff, Inventing Eastern Europe, 101.
} 
and self-congratulatory image of the 'European' and the 'West' has been constructed." 36 The Balkans are turned into a primitive place between the Orient and civilized Europe in order to help bolster western Europe's theory of cultural superiority.

Wolff and Todorova both use Edward Said's theory of "Orientalism" to support their vision of a changing Europe. Said supported a theory that the west began to use a paradigm based on an old backward but mystical orient that they contrasted with a more rational and progressive Europe.$^{37}$ Both Wolff and Todorova use this theory to help explain the use of an eastern Europe in the creation of a western European view of itself. Both Wolff and Todorova agree that the Enlightenment philosophers and historians created a bridge between Western Europe and the Orient and called it Eastern Europe. ${ }^{38}$

Sometime between the seventeenth and the twenty-first centuries, Poland, along with the other sections of Europe, became "Eastern." After 1989, there has been a push to reclasify Poland, Hungary and Bohemia as central Europe while continuing to put the lands beyond modern Poland into the sphere of "Eastern" Europe ${ }^{39}$ Poland's attempt to separate itself from Eastern Europe, while creating a new geographic identity has caused Polish historiography to branch out into many different paradigms. These self realizations range from apologetic histories to the creation of a nationalism rooted in martyrdom. It becomes important to both understand the value of these histories and the focus of their biases.

\footnotetext{
${ }^{36}$ Todorova. Imagining the Balkans, 188.

37 Edward Said. Orientalism (New York: Vintage Books. 1979).

38 Todorova, Imagining the Balkans, 188 and Wolff, Inventing Eastern Europe, 155-156.

39 Todorova, Imagining the Balkans, 144-146.
} 
Some authors, such as Oscar Halecki, tend to blame the vision of Poland as Eastern European and backward on the powers that partitioned it during the eighteenth century. Halecki puts the blame largely on the Prussians and their attempt to eradicate Poland from history. His essay "The Problems with Polish Historiography" blames historian-philosophers such as Leopold von Ranke for Poland's reputation as a backward land in Eastern Europe. Halecki's essay also discusses how certain historians have become overly romantic in their writing. He explains how they tended to “... set the vision of an exceptionally perfect nation whose martyrdom was to redeem the wickedness of the others...propagated exclusively by poets, whose messianic inspired certain trends in the Polish philosophy of history." 40 Yet he still blames this attempt at turning Poland into an almost Christ-like figure on the continual need for Polish writers to fight the Prussian historiography on Poland.$^{41}$ Halecki emphasized that many historians attempted to be more objective in their study of Polish history. He asserts that even these authors were still undermined by the Prussian school of historiography.

Halecki's rhetorical tendency to blame one of the partitioning powers for Poland's alienation is used in several other histories such as Adam Zamoyski`s The Polish Way, ${ }^{42}$ Karin Friedrich's The Other Prussia, ${ }^{43}$ Daniel Stone's The Polish-Lithuanian State, 1386-

40 Oscar Halecki. "Problems of Polish Historiography," Slavic and Eastern Review: American Series, vol. 2. Issue I (March. 1943), 225.

${ }^{41}$ Halecki. "Problems of Polish Historiography." 224.

42 Adam Zamoyski. The Polish Hav: A Thousand-Year History of the Poles and Their Culture (London: John Murray Publishers, 1999).

${ }^{43}$ Karin Friedrich. The Other Prussia: Roval Prussia, Poland and Liberty, 1569-1772 (New York: Cambridge University Press. 2000). 
$1795^{44}$ and Jerzy Lukowski's Liberty's Folly. ${ }^{45}$ Although Lukowski mentions that his

"... finished product is somewhat different to what [he] imagined when [he] first put pen to paper. It is not a revisionist work and, for many readers, it may well reinforce old stereotypes." All these historians begin their books by bringing up the problems within Polish historiography due to its constant competition with the histories based on Prussian, Russian and Austrian historiography. There is a need to show that the "crime" of the partitioning powers ran deeper than their decision to divide up Poland. They were also the ones who began the trend towards Poland's alienation from the rest of Europe, especially the history of the Commonwealth Connor praises.

Connor agrees with Daniel Stone that the origins of the Commonwealth's decentralized politics began during the reign of the Piast Dynasty, during the tenth to fourteenth centuries. The origins of the actual Commonwealth are found within the personal union of Wladyslaus Jagiello of Lithuania (1386-1434) and Jadwiga of Anjou of Poland (1373-1399). As a part of his marriage contract to Jadwiga, Wladyslaus agreed to baptize his people and unite them to the kingdom Poland under his rule. The two kingdoms continued to be semi independent until Sigismund August (1548-1572) united them in the Union of Lublin in 1569 before his dynasty, the Jagiellonians, male line died out. From then on the Commonwealth became a complicated kingdom of two provinces merged together and ruled by a senate who elected their kings.

\footnotetext{
${ }^{44}$ Daniel Stone. The Polish-Lithuanian State.

45 Jerzy Lukowski, Liberty's Folly: The Polish-Lithuanian Commonwealth in the Fighteenth Century: 1697-1795 (New York: Routledge. 1991).

th Lukowski. Liberty's Folly, xiii.
} 
Under the Jagiellonians the Commonwealth extended into the Baltic area after subduing the Teutonic Knights at the battle of Grunwald in $1410 .{ }^{47}$ Then, after thirteen years of war in 1466 western Prussia became Polish territory while eastern Prussia became a semi autonomous vassal of the Commonwealth. ${ }^{48}$ In the east Lithuania took control of western Russia, Livonia and the Ukraine. Ukraine would be given to Poland in 1569 as part of the Union of Lublin and the Vasa Dynasty would lose Livonia in 1621. The throne of the Commonwealth would become elective after Sigismund August died in 1572. Each elected king would have to swear to uphold the freedoms that the Jagiellonians had granted the nobility and swear to continue to promote religious toleration. $^{49}$

From the Jagiellonian period until the end of the Commonwealth in the eighteenth century, the nobility continued to gain more power ${ }^{50}$ As the nobility gained power and the Commonwealth became the major producers of grain for Europe, the peasants were forced back into serfdom in order to create a continuous and controlled form of labor in the grain fields. ${ }^{51}$ The Commonwealth would survive into the eighteenth century until it was finally partitioned by Prussia, Russia and Austria in $1795 .{ }^{52}$ Historians have come up with many reasons for this decline. They blame the nobility, religion and the partitioning

\footnotetext{
4` Zamoyski, The Polish IIav, 46-47.

18 Norman Davies. God's Playground: A History of Poland in Two Lolumes. Volume I: The Origins to 1795 (New York: Columbia University Press. 1982). 256.

49 Daniel Stone, The Polish-Lithuanian State, 116-120.

50 Zamoyski, The Polish Way, 70.

51 Davies, God's Playground, 227-229.

52 Stone. The Polish-Lithuanian State, 287-288.
} 
powers for the final disappearance of the Commonwealth. The nobility is retarding forces within historiography, the Counter-Reformation is blamed for the loss of religious equality within the Commonwealth and the partitioning powers are depicted as sinister despotic governments bent on conquering the Commonwealth.

Adam Zamoyski's book, The Polish Way, is largely an attempt to explain the Polish ethos and its connection to growth and conquest throughout the centuries. Zamoyski also sees Poland as almost achieving a democratic political body, but then being overrun by despotic monarchs, Counter-Reformation politics and a greedy nobility. ${ }^{53}$ Zamoyski concludes that the nobility became more exclusive and wealthy. They were becoming less concerned with the survival of the parliament and more detached from the world around them ${ }^{54}$

Zamoyski blames the Poles for their alienation. Although he blames the Prussian and Russian historians for twisting Polish history to suit their needs, he also believes the Poles pulled away from "Western" Europe towards the period of their decline. This theory is also echoed in the writings of W. F. Reddaway, J. H. Penson, O. Halecki, and R. Dyboski's Cambridge History of Poland. ${ }^{55}$

Karin Friedrich's The Other Prussia attempts to inform the reader about Royal Prussia, also known as Polish Prussia, in order to show the historiographic community that Prussia, like Poland, has a very intricate and misunderstood past. She asserts that her reasons for writing The Other Prussia are due in part to the Prussian desire to ignore any

\footnotetext{
53 Zamoyski, The Polish Hay, 150-151.

54 Zamoyski. The Polish IIay, 125.

55 Reddaway, The Cambridge History of Poland, 578.
} 
Polish connection to Prussia and emphasize a historic connection between the heroic Teutonic Knights and the Prussia under Frederick II the Great (1712-1786). ${ }^{56}$ Daniel Stone's The Polish-Lithuanian State, focuses on the rise and fall of the Commonwealth, how it gained in power and formed into a Commonwealth of nobility, and subsequently began to grow corrupted by internal instability and the external pressure from the partitioning powers. Stone, Zamoyski, Lukowski and the Cambridge History of Poland tend to show that, towards the end of the eighteenth century, the members of the Commonwealth were attempting to perform some reforms on their constitution to create some form of weak central government.

Both Friedrich's 2000 publication The Other Prussia and A. F. Pollard's 1892 publication, The Jesuits in Poland support a paradigm of political disorder due to the Jesuits' introduction of the Counter-Reformation. Though the two texts are separated by 108 years, they continue a similar paradigm. The Counter-Reformation was at the root of Poland's decline. Both portray the Jesuits as the ones who disrupted the delicate structure of the Commonwealth. They both give a depiction of a kingdom that had survived into the sixteenth century only to fall apart with the civil wars and CounterReformation of the late seventeenth and early eighteenth centuries..$^{57}$ Friedrich and Pollard emphasize the growth of a chaotic parliament and constant pressure from stronger monarchies outside the Commonwealth.

\footnotetext{
${ }^{56}$ Friedrich. The Other Prussia. 3-4.

57 Friedrich. The Other Prussia. 108-111 discusses how the Jesuits antagonized the burghers of Royal Prussia. and A. E. Pollard, The Jesuits in Poland: The Lothian Essay, 1892 (New York: Haskel House Publishers Ltd., 1971), 80-85 depicts the Jesuits" constant meddling as a reason for both the Prussian betrayal and the Cossack uprising.
} 
Stone's book paints a portrait of a parliamentary government that began in the fourteenth century during the last two members of the first Christian dynasty, the Piasts and continued to grow in power during the golden years of the Lithuanian-born Jagiellonian Dynasty. He follows the growth of a decentralized government and the cultural and economic trends that followed this growth. His history of the Commonwealth continues throughout the elective dynasties of the seventeenth and eighteenth centuries. Stone discusses the failings of the parliamentary government of the eighteenth century and how several groups in Poland attempted to centralize the kingdom through either the creation of a constitutional monarchy or a constitutional republic. He mentions how these leading monarchs, nobles, generals and intelligentsia found themselves often pitted against each other or the partitioning powers. ${ }^{58}$

Jerzy Lukowski's text Liberty's Folly is an examination of how the parliament of nobility began to disintegrate into political factions led by powerful magnates bent on keeping total control. His vision of the Commonwealth emphasizes the oppressive qualities of the nobility and their desire to keep the peasants under serfdom. Lukowski admits that the Commonwealth attempted to reform itself and may have been able to transform itself into a constitutional government in the same way that the United States and England formed their governments. He accuses the partitioning powers for helping to retard this development. ${ }^{59}$ In his conclusion Lukowski explains that the errors of the seventeenth century were beginning to be addressed by later kings and officials in Poland. Lukowski explains, “... no matter what the enlightened despots and their friends

\footnotetext{
58 Daniel Stone. The Polish-Lithuanian State. 269-272 and 277-288.

59 Lukowski, Liberty's Folly, 267.
} 
among the philosophes affected to think, the Polish-Lithuanian state which Russia, Prussia and Austria tore apart was not in a condition of terminal decline or cultural barbarism." ${ }^{(1)}$ The study of the Commonwealth of the seventeenth and eighteenth centuries often focuses on where the Commonwealth went wrong and who was at fault for its eventual decline. Although he was a critic of the Commonwealth's nobility even Lukowski text enforces the paradigm that the partitioning powers for their participation in erasing the Polish-Lithuanian Commonwealth.

Norman Davies reexamines the historic information already developed and expands it to encompass sections of historiography that had not been closely examined. He has produced two histories that attempt to include Poland in the overall scope of history, not as a place of conquest or anarchy but as a once-powerful kingdom. He focuses solely on Polish history in his book God's Playground and includes the Poles in a broader discussion about European history in his text Europe. ${ }^{61}$ In God's Playground, Poland is depicted as a kingdom that must develop in spite of outside forces such as the Holy Roman Empire. The kingdom becomes a Commonwealth that could have become a great Republic but fell into anarchy during the late seventeenth century. ${ }^{62}$ Davies also opens his histories with a tendency to point a finger at the "western" Europe or the partitioning powers for Poland's tendency to be seen as eastern and backward. In Europe, Davies attempts to include Poland in the greater discussion about European civilization and to portray it as a force that helps with the overall evolution of that civilization.

\footnotetext{
6) Lukowski. Liberty's Folly, 266.

61 Norman Davis, Europe: A History (New York: Oxford University Press. 1996), 26-30.

62 Davies. God's Plavground, xii.
} 
Davies lets the reader know that he wishes to cover many European peoples that are often forgotten in histories of Europe. He explains, " [t] he geographical spread aims to give equitable coverage to all parts of the European Peninsula from the Atlantic to the Uralsnorth, east, west, south, and center. At every stage, an attempt has been made to counteract the bias of 'Euro centrism' and 'Western civilization'..." ${ }^{93}$ Davies continues this argument about western European biases against eastern Europe.

Jozef Andrzej Gierowski's essay, "The International Position of Poland in the Seventeenth and Eighteenth Centuries," supports a view that Poland's decline on the lack of central authority. Gierowski writes that Poland, “...lacked an important tool in meeting the numerous and increasing challenges present to it by its neighbors who were in the process of creating powerfully centralized bureaucratic administrations while Poland was sinking ever deeper into parliamentary paralysis." ${ }^{64}$ Although most of the authors mentioned in this thesis put some blame on the nobility, Gierowski makes them the major factor in Poland's decline.

Janusz Tazbir's "The Fate of the Protestantism in the Seventeenth Century" explains that Poland had managed to survive the Reformation without any major political or intellectual problems. This changed, however, once the Counter-Reformation overtook the Commonwealth; "... the disappearance of pluralistic forms of worship brought about intellectual stagnation in the camp of the victors, a result common enough not only in the

${ }^{63}$ Davies, Europe, viii.

64 Jozef Andrzej Gierowski, "The International Position of Poland in the Seventecnth Centuries." A Republic of Nobles: Studies in Polish History to 1864 (New York: Cambridge University Press, 1982). 221. 
seventeenth century...." ${ }^{05}$ Tazbar echoes the themes of Friedrich and Pollard in his essay. He also believes that the Jesuits had a major role in helping to cause the internal chaos that eventually lead to the Commonwealth's demise.

Not only do these sources support some of the points raised in this thesis, but they also demonstrate many of the issues faced in writing a history of the Polish-Lithuanian Commonwealth. There are also sections of Connor's history that have a different argument from the more modern historiography. Connor was angry with the nobles for not being more rebellious during the election of King August and disagreed with the use of central authority over a parliament or senate. ${ }^{66}$ After his own experiences in England he distrusted any form of central authority.

It is true that they are only a small section of the Polish historiography. Yet they show the problems inherent in trying to figure out not only Poland's place in European history, but also why it may be important in studying this rich and compelling nation's history. It is easy to see how historians could emphasize a romantic vision of the rise and fall of the Commonwealth. Yet it is also easy to understand how an author could envision this same Commonwealth as oppressive and perhaps in need of extreme changes.

In all histories there are five major matters under dispute: the nobility, the kings, the government, religion, and the oppression of the serfs. All of these subjects become important in the understanding of Connor's The History of Poland. In Connor's history Poland is hard pressed by the intrigues of foreign courts, but continually resists those

\footnotetext{
65 Janusz Tazbir, "The Fate of Polish Protestantism in the Seventeenth Century," A Republic of Nobles: Studies in Polish History to 1864 (New York: Cambridge University Press. 1982), 217.

${ }^{66}$ Connor. The History of Poland,
} 
powers from within and without that attempt to eliminate the free parliament. Connor does not necessarily forget the oppressive nature of the nobility, but instead sees it as part of a whole European world. He gives the historian a vision of the Commonwealth through the lens of a man who understood the way kings and parliaments fought each other, how the nobles and elites asserted their rights over the lower classes and how a trend towards despotism was beginning to find favor in kingdoms such as France. Although Connor uses models to base his theories on, he is still forced to base his material on some form of primary source or personal observation. He writes a history based on his own notes. He bases his history of Poland on both primary and secondary sources found in the Commonwealth. Connor's Poland accepts that these nobles are not perfect. They can be self indulgent and greedy. Yet they do something that other kingdoms at the time may not have done. They gave a large minority of people a right to vote for both their rulers and the politics they would be ruled by. They saw themselves as equals regardless of religious and ethnic origins.

Connor's The History of Poland gives the reader a look at a Poland that does not apologize for the nobility, but rather accepts that it was one of a few commonwealths left in Europe that by the end of the seventeenth century seemed to be standing the test of time. That this commonwealth did not survive the end of the eighteenth century may have been more of a problem due to its position in Europe and the increased support in the easily maintained and more organized despotic government. Many modern histories mourn the Commonwealth's inability to centralize. Connor's Poland is a testament to the sacrifices that centralization meant. A change to central government did not necessarily mean freedom for the lower classes. It is easy to lose perspective through hindsight. 
In a time of growing central authority, Connor's history gives its reader a chance to examine a Commonwealth that was still strong by the end of the seventeenth century. What happened in the eighteenth century is a product of many variables that may have been different if the Commonwealth had been in a different place at a different time. If it was separated by a sea or ocean it may have been able to come into its own without the threat of conquest. The modern perspective of Poland is clouded by Wolff and Todorova's Enlightened "western" European bias against the east and the years of historiography produced by Halecki's partitioning historians. Even Connor saw the Commonwealth's opposition in the forms of France and Germany's desire to control the future of Polish politics.

This thesis will examine Connor's 1698 publication, The History of Poland in order to show that one of the progressive thinkers of the seventeenth century believed the Commonwealth was a progressive European parliamentary government that could serve as a model for a struggling English parliamentary government, thus supporting Wolff and Todorova's vision of the eighteenth-century creation of backward eastern Europe. 


\section{Chapter II. Searching For A Commonwealth}

The life of Bernard Connor has been widely discussed within the scientific sphere of academia. He has been the subject of several biographical studies. Two of the more extensive biographies are Davis Coakley's book, Irish Masters of Medicine ${ }^{1}$ and Baruch S. Blumberg and Jean L. Blumberg, "Bernard Connor (1666-1698): and His Contribution to the Pathology of Ankylosing Sodalities." According to Coakley, Connor was "... one of the first doctors to champion a scientific approach to the diagnosis and treatment of disease, and he was also the first to describe the bone hardening disease now known as ankylosing sodalities. ${ }^{3}$ He used the human anatomy to diagnose and treat various ailments. The Blumbergs' essay summarizes most of the physician's life while focusing on his work with Ankylosing Sodalities. Coakley's biography goes into more detail.

Coakley discusses Connor's controversial attempt to use scientific methodology to prove the existence of religious phenomenoa. Whether using anatomy and scientific method to help treat sickness or understand the world around him, Connor continually found himself chafing against the English political world. Many of his ideas caused controversy in England.

Coakley emphasizes a link between Connor and the O' Connor family. He explains, "Very little is known about his early years other than he born in Kerry around

\footnotetext{
1 Davis Coaklcy. Irish Masters of Medicine ( Dublin: Town House, 1992).

2 Baruch S. Blumberg and Jean L. Blumberg. "Bernard Connor (1666-1698): and His Contribution to the Pathology of Ankylosing Sodalities," Journal of the History of Medicine and Allied Sciences. vol. 13 (New York: H. Shuman. 1958). 349-366.

${ }^{3}$ Coakley. Irish Masters of Medicine, 15.
} 
1666 and his father was named Bernard. In his Irish Pedigrees, O' Hart claimed that Connor was a member of a branch of the O'Connor Kerry family, lords of Kerry, whose seat was at Carrigafoyle." ${ }^{\text {T }}$ The Blumbergs, on the other hand, questions Connor's exact connection to the Kerry family. ${ }^{5}$

It was Connor's belief in anatomy and science as an answer to major questions about health and worldly mysteries that caused him to question how liberal the English intelligentsia really were. It was his connection with the old Irish Catholic O'Connor family that made him understand the failings of English politics. Both of these doubts helped to form Connor's perspective on the Polish-Lithuanian Commonwealth. In the Commonwealth, he found a place that allowed at least some form of religious and ethnic toleration within a government that was somewhat decentralized. In King John III Sobieski, he found a place willing to listen to new scientific approaches toward human understanding that he had missed in England. After understanding the world in which Connor grew up and the biases he portrays in his preface, it comes as no surprise that he would turn the Polish-Lithuanian Commonwealth into an Eden. In so doing he brings into question whether the view of the backward Poland is not a historic "truth" but rather another interpretation.

\section{Connor's Life In England}

As a member of the O'Connor family, Connor would have been attached to one of the old Irish noble lines. Under the stress of colonization this family would have fallen from being royalty and become petty nobility in English eyes. They were still considered

4 Coakley. Irish Masters of Medicine 15.

5 Blumberg. "Bernard Connor (1666-1698)," 349 
a magnate-like family in Ireland that propagated an aura as the saviors of the Irish. In Kevin Whelan's book, The Liberty Tree, mentions that even as late as 1786 members of the O'Connor family were still attempting to keep some semblance of power in Ireland. Whelan goes on to explain that the O'Connor family had always been a family of Irish leaders. He explains that "[i] $n$ the early eighteenth century Denis O'Connor, head of the family descended from the last High King of Ireland, maintained an Irish master, fencing master and dancing master while patronizing the harpers, Catholic clergy and 'reduced gentlemen' of his neighborhood." While they lost status as high kings of Ireland, the O' Connors still held sway over the Irish people in the same way that the great nobles of Poland-Lithuania controlled those under them.

Connor was born an Irish Catholic. His Catholic origins would have been an obstacle to his ability to obtain any high positions in England under the new legislation put forward by the 1673 parliament. According to Stanford E. Lehmberg in his 1992 survey of the British Isles, "[i] n 1673 word of the treaty's secret clauses leaked out. Parliament was irate. It forced Charles to cancel the Indulgence. It then passed the Test Act, which was meant to exclude Catholics from government office and military command." Many of Charles supporters had faced religious persecution from the Anglican section of the government. However, any attempt on Charles' (1660-1685) part to give forgiveness or Indulgences to these Catholic supporters who wished to be absolved of acts deemed sinful by the English government and religious elites was

\footnotetext{
6 Kevin Whelan. The Tree of Liherty: Radicalism, Catholicism and the Construction of Irish Identity, 1760-1830 (Ireland: Cork University Press, 1996), 18.

Stanford E. Lehmberg. The Peoples of the British Isles: A New History, From Prehistoric Time to 1688. vol. I (California: Wadsworth Publishing Company, 1992), 281.
} 
blocked by the English Parliament who forced him to pass the Test Act. ${ }^{8}$ Parliament's acceptance of the Test Act was an attempt to not only exclude Catholics from top offices, but also to convert would-be ethnic intelligentsia. Parliament made sure that those who were not of Anglo and Anglican origin within the kingdom were either forced to convert to an English view of the world or excluded from teaching anything that might have contrasted with the Anglican perspective.

Lehmberg points out that this new law was, "[s] imilar to the earlier Corporation Act, it required officeholders to receive communion in the Church of England and renounce the Catholic doctrine of substantiation." Connor's connection to high-ranking Irish Catholic nobility caused him problems in his pursuit of a medical education.

Blumberg mentions that on his 1695 return to England, "it is presumed that he had by this time been received into the Established Church of England for, as a consequence of the Test Acts of 1673, he would not otherwise have been permitted to attend the universities or to practice in London."1" Connor was one of these Catholic converts who had firsthand experience with English conservative politics. Norman Davies' book The Isles explains how, "[i] $n$ the changed Political climate, an important sector of native Irish took to English ways." cultural identity to fit in with the English political system.

\footnotetext{
$\times$ Lehmberg. The Peoples of the British Isles, 180-182.

9 Lehmberg. The Peoples of the British Isles, 181.

${ }^{10}$ Blumberg, "Bernard Connor (1666-1698)," 354.

11 Davies. The Isles, 568-569.
} 
He also lived through the later century of English conquest in Ireland. The English attempted to conquer this island by strengthening Protestant colonization by force if necessary. Throughout the seventeenth century, England continually attempted to force the Irish and Scottish population into subjugation through colonization and cultural conquest, Lehmberg explains to his readers that "[i] n ruling Ireland, Oliver Cromwell (1599-1658) extended the policy of confiscation and colonization, so often regarded as a panacea for Irish troubles." ${ }^{12}$ Cromwell's mission was to help protect Protestant colonizers while suppressing the Irish revolutionaries that had helped to foster the Massacre of $1641 .{ }^{13}$ The Irish Catholics began to slaughter the homesteaders sent to colonize Ireland for the crown of England. Whenever the parliament gained control of the government there was no solidarity between nobles or officials. Rather the English parliament continually attempted to take over the other ethnic minorities in the English Commonwealth.

This attempt at suppressing the ethnic and religious minorities in England often took the shape of forced colonization by Protestant factions and religious persecution on a political scale. Davies goes as far as to compare the English colonization of Ireland with the displacement of Native Americans in the New World. Davies writes, "[t] he native Irish were to play the same part as the native Americans." ${ }^{\prime 4}$ The English parliament wanted to end Irish ties to their Catholic religion and Celtic culture even if it meant treating them like the peoples of the New World.

\footnotetext{
12 Lehmberg. The Peoples of the British Isles, 270.

${ }^{13}$ Lehmberg. The Peoples of the British Isles, 253.

${ }^{14}$ Davies, The Isles, 568.
} 
In a letter to the parliament in 1689 entitled, "Aphorisms Relating to the Kingdom of Ireland," Sir Richard Coxe wrote a list of reasons for a new series of English expeditions into Ireland. Connor may have blamed the Poles for exhibiting similar biases toward the Cossacks within The History of Poland. According to Coxe, the English should help to keep the people of Ireland in check due to their tendency to conceive England, "... to be obstinate Hereticks, and therefore they have often invited the Pope, French and Spaniard to accept of the Government of that Kingdom." ${ }^{\prime 5}$ After listing many other reasons to invade and control Ireland, Coxe ends with a recommendation to include a new English garrison in Ireland. He fears that without a strong army, the province “... will be as Unsafe and Troublesome as in time of War." ${ }^{16}$ Coxe supports a military occupation of Ireland in an attempt to support drastic colonization. Connor was alive during the Glorious Revolution when William of Orange and Mary Stuart took the throne from James II in 1688. Again the Irish become one of the victims of this power struggle. The Irish allied with James II and began to engage the forces of William in the hopes of putting the Catholic-friendly French-supported Stuart monarch back on the throne. When James II finally gave up and left England those Irish supporters, or Jacobites, were left to feel the wrath of the new English king and Parliament. ${ }^{17}$ This was another factor in Connor's distrust of the Saxon king August II. William of Orange, who ruled England from 1689 to 1702 , had ties to the Holy Roman Empire before he married Mary Stuart,

\footnotetext{
${ }^{15}$ Sir Richard Coxe, Aphorisms Relating to the Kingdoms of Ireland. (London: For Joseph Watts. 1689). 3. 16 Coxe. Aphorisms Relating to the Kingdoms of Ireland, 6.

${ }^{1\urcorner}$ Davies. The Isles, 616-618.
} 
who jointly ruled England with him from 1689 to 1694 . Connor believed allying with French and German political figures had fatal prospects.

This political atmosphere caused Connor to leave England in order to continue his studies in France. When he was in his early twenties, he was sent off to France to study medicine. He graduated from Rheims in 1693 with a doctorate in Physic ${ }^{18}$ He spent about three years teaching in Paris. Then he met the Chancellor of Poland and became friends with his sons. The Blumbergs state "[i] $\mathrm{t}$ was through his court connections that he made the acquaintance of two sons of the High Chancellor of Poland who were visiting the country. There were strong connections between the Polish and French kingdoms at this period. The wife of the Polish monarch was French and received a subsidy from Louis XIV [who reigned from 1643-1715]." ${ }^{19}$ Connor agreed to follow the two nobles back to Poland.

His fellow travelers took him through several kingdoms. Coakly expands on how Connor's travels lead him “... on a circuitus route, seeing Italy, Sicily, Germany and Austria on the way. Connor took advantage of this to visit the leading medical centres in Europe, exchanging ideas with scientific medical men...." "2" Both Coakley's and the Blumbergs' texts portray Connor as the consummate scientist always ready to learn something new from the people around him. Coakely also mentions that Connor spent much of his time healing English travelers who happened to cross his path. ${ }^{21}$ Connor

\footnotetext{
${ }^{18}$ Coakley, Irish Masters of Medicine, 15.

19 Blumberg. "Bernard Connor (1666-1698)," 352.

20) Coakley, Irish Masters of Medicine, 16.

21 Coakley, Irish Masters of Medicine, 16.
} 
dedicated each new chapter of his history to his fellow English travelers in the form of letters addressed to them. ${ }^{22}$

Once in Poland, Connor became a favorite of King John III Sobieski. Sobieski had been a dominant figure in Polish and Central European politics throughout his reign. He was becoming sick and over-weight and needed a physician to watch over him. Sobieski enjoyed Connor's ideas about using anatomy to understand medicine and believed that he would be able to help either cure or postpone the advancement of his illnesses. Coakley informs the reader that "[i] $\mathrm{t}$ was an onerous post as the king did not enjoy good health; he was overweight, had intermittent oedema, and respiratory problems, and he also suffered from gout. ${ }^{י 23}$ Connor became a member of the king's court.

According to Coakley, Connor developed several enemies at the king's court because of his beliefs in anatomy. Many of the Polish physicians thought the use of anatomy was beneath them. ${ }^{24}$ The Blumbergs describe Poland as "wild" and "remote," but make no mention of problems within the court. ${ }^{25}$ Connor does discuss moments within this history where Sobieski had him debate several clergymen led by a Jesuit named Father Vota, but he does not acknowledge that as his reason for leaving. Connor explains that he "... longed to be out of that remote Country (tho I had been not a twelve

22 Connor. The History of Poland. 2.

23 Coakley, Irish Masters of Medicine, 16.

24 Coakley, Irish Masters of Medicine, 17.

25 Blumberg. "Bernard Connor (1666-1698)," 352. 
Month in it) to come to England. ${ }^{26}$ Connor does not mention any form of conflict. He blames his exit on homesickness “... for tho the King and Queen had a great deal of Kindness for me, and Prince James... promis'd me a considerable Pension after the King's death... having never had any mind to engage my self to live in any Foreign Country, I resolv'd to come out of that Kingdom." ${ }^{27}$ He wanted to return and begin a medical career in England.

Connor left Poland as the physician to the princess of Bavaria. After she passed away, he traveled to Holland ${ }^{28}$ From Holland, Connor returned to England now under the co-rule of William of Orange and Mary Stuart. He changed his name from O'Connor to Connor in 1694, and attempted to find work as a physician in London. From London he moved to Oxford where he was accused of being a Jacobite spy. The Blumbergs point out that as soon as Connor entered England he was already the subject of controversy and confusion:

Dr Robert George of Oxford, writing to Trimball Secretary of State] in July 1695 , states that he had heard of Connor, and although Connor professed to be Polander... (which we have no evidence he ever attempted to do) he was in fact an Irishman and that he had come to Oxford not to instruct in Physick but to excite the young men to rebellion against the throne and stir up Jacobite sympathizers. ${ }^{29}$

The Blumberg mention how Connor had not only changed his name but was accused of calling himself a Polander and not an Irishman. This is important when discussing the reasons behind Connor's need to write The History of Poland. He was

${ }^{26}$ Connor, The History of Poland, 193.

2- Connor. The History of Poland, 194.

28 Blumberg. "Bernard Connor (1666-1698)," 354.

29 Blumberg. "Bernard Connor (1666-1698)," 359. 
attempting to hide his Irish origins on his reentrance into England. However the Blumbergs mention that there is no hard evidence to prove claims that he was a Polander or a Jacobite. The issue over his decision to declare himself a Polander sheds light on the affection this man had for his adopted Commonwealth. The free use of the label Jacobite also demonstrates how willing English officials were to condemn anyone that seemed of questionable background. This slander caused Connor the first of three incidents where he had to defend himself against the English medical field. Although Connor had several enemies within the English medical academy, he was still elected to the Royal College of Physicians in London. Coakley mentions that during his time in England, Connor had a tendency to write and report on controversial issues dealing with anatomy and medical philosophy. This “....tendency to voice critical opinions openly and candidly on different subjects was frequently resented, despite please for tolerance...."3n' Hs desire to understand the scientific makeup of the human animal was also the thing that alienated him from other English thinkers.

It was one of his treatises on the subject of miracles and science that led to the second major controversy surrounding his personal ideologies. This second outrage occurred in 1697, when Connor published his text, Evangelium Medici. "The book caused sensation because he appeared to suggest that the miracles in the Gospel could be explained by natural means." ${ }^{31}$ In an apology entitled, "His Grace **** from Dr.

Connor," Connor explains that the text was supposed “... to convince our Scepticks in Religion, the Deists, who must give their Assent, when they have the same evident

\footnotetext{
311 Coakley, Irish Masters of Medicine, 20.

${ }^{31}$ Coakley, Irish Masters of Medicine, 22
} 
Reason to conceive the Possiblility, to believe the Truth of such Miracles..." ${ }^{32}$ Connor goes on to explain that he, “... conceived the Laws of Motion [could] be suspended three different ways, and by one or more of those Laws of Suspension, it is easie to solve clearly all Miracles, as it is to explain the most evident Effects of Natural Causes, by the common Laws of Motion." ${ }^{33}$ Connor attempts to gain the king's favor by explaining that he wanted to use motion in order to defend the Christ's miracles against those who would have debased them.

Coakley mentions that Connor told a friend of his that he would continue to be a doctor and leave scientific philosophy behind. ${ }^{34}$ It was in the middle of his controversy with the Evangelium Medici that he began to contemplate writing The History of Poland. According to Coakley, "[r] ather than delay the publication of his Polish material he asked a friend [John Savage] to complete the editing of his work. ${ }^{35}$ Connor presented a copy of his book to the Journal Book of the Royal Society on February 23,1697. The Blumbergs mention that there was a very long review, "...preserved in the classified papers of the Society." ${ }^{\prime 36}$ Connor would die in 1698 at the age of thirty-two.

The young doctor would have a third scandal surface due to his death. He was found with a Catholic priest at his bedside. His eulogizer, William Hayley, attempts to dispel the rumor that Connor was secretly a Catholic, by telling the audience that he was

\footnotetext{
32 Connor. A Copv of a Letter Sent His Grace, 1.

${ }^{33}$ Connor, The IIistory of Poland. 2.

${ }^{34}$ Coakley, Irish M Iasters of Medicine, 24.

${ }^{35}$ Coakley, Irish Masters of Medicine, 24.

${ }^{36}$ Blumberg, "Bernard Connor (1666-1698)," 360.
} 
a "... a true penitent Member of the Church of England...." ${ }^{37}$ Hayley blames the confusion over Connor's death bed blessing on a "Papist" plot to take his soul while he was out of his mind. "But I confess I believe his judgment was now quite decayed, and that he did not know what he did; for he was though dying by those about him, though he recover'd out of Agony and liv'd till next day." ${ }^{38}$ Connor's short life was one of adventure, learning and continual controversy. It is also a catalyst for the views he held on the Polish-Lithuanian Commonwealth. He was a product of an England that still wavered between parliamentary rule and despotic government. It was also a place where only English elites from the Anglican Church held sway.

\section{Connor's View of Poland}

Connor's experiences in life are a driving force behind his depiction of the Polish Commonwealth in his The History of Poland. The author emphasizes Poland's free parliament and the way the senate tended to be the voice of the Commonwealth. He also continually mentions the way the parliament or senate in Poland was not only Polish and Catholic but a diverse group of nobility picked from all religions and ethnic groups.

In Connor's book, the table of contents on page $\mathrm{x}$ is separated into chapters labeled with the titles of correspondences to friends and acquaintances. This method of chapter formation was either due to his attempt to turn his personal notes into a history or a stylistic method to make each chapter more personal. For example, Connor dedicates his first chapter to the Lord of Dartmouth "Letter I. To the Right Honorable William, the

\footnotetext{
3. William Hayley, A Sermon Preached. 1t The Funeral of Doctor Connor. (London For Jacob Tonson. 1699), 32.

38 Hayley. A Sermon Preached At The Funeral of Doctor ('onnor, 33.
} 
Lord of Dartmouth, of the Origins of the kingdom of Poland, with the Succession and Remarkable Actions of its First Dukes from the Years 550 to $830 .{ }^{39}$ Whether these chapters were originally personal correspondences or altered to look like letters the format gives the author a personal connection with the reader. It also shows that Connor had many friends in high places who devoted themselves to lives in politics. This use of letter formation helps to give his research more legitimacy.

Connor also emphasizes his closeness to ambassadors who worked with the Polish-Lithuanian Commonwealth. An example of such a chapter is the "Letter II. To the Right Honourable Laurence Earl of Rochester, Embassador from his Majesty Charles II. Into Poland, Containing the second and third Classes of the Kings of that Country, or the Succession and Remarkable Actions of the Families of Piastus and Jegiello, from the Year 830, to the Year 1574," which was dedicated to a recently-retired English ambassador to Poland. Connor remarks about how the Earl of Rochester was such an exceptional emissary that " $[t]$ he esteem the Court of Poland profess'd for your Lordship's Memory was fresh enough in my time to convince me, that you were thoroughly acquainted with the Genius and Constitution of that Nation...."41 Thus, Connor believed that an account of the Piasts, the first Christian ruling family of Poland, may have been of interest to the Earl of Rochester. The table of content like the bibliography and footnotes are used to give Connor an air of scientific professionalism in his history.

${ }^{39}$ Connor. The IIistory of Poland, 2.

41) Connor, The History of Poland, $\mathrm{x}$-xi and xii-xiii.

41 Connor, The History of Poland, 20. 
Connor uses his skill as a scientist to include a detailed bibliography of Medieval and Early Modern texts and footnotes in an attempt to make his model of Poland more scientific. His citations consist of the author and title in its Latin form. As is the case with the texts, Johannis Boteri Poloniae Descripto and Johannes Duglossus Annales Polonorum, the titles consist of an author and subject. Where there is no author in the title he either attempts to include one after the text, or does not include that information. He acknowledges that he was not a historian and had to depend on others for his understanding of Polish history. "I have gather'd from the best Polish Authors, learned from the most Intelligent Natives, or observed my self...." ${ }^{12}$ He uses these sources to foster an image that he is only writing down what can be proven. Connor uses the list to reinforce his credentials as a researcher in the same way Early Modern rhetorical arguments used footnotes and bibliographies to back their arguments. Rhetorical works such as Richard Collons 1698, The Cause of England's Misery and Samuel Johnson's 1690, Remarks Upon Dr. Sherlock's Book use footnotes to support their arguments. ${ }^{43}$ Collons uses outside information to prove himself innocent of charges, while also scolding the royal court of England for becoming corrupted through pretenders and clergymen. Johnson uses footnotes and a bibliography to give him a more informed argument against Dr. Sherlock's theory about the "Divine Right of Kings."

\footnotetext{
${ }^{42}$ Connor. The History of Poland, viii.

${ }^{43}$ Richard Collins, The Cause of England's Misery (London: E. P., 1698) and Samuel Johnson. Remarks L'pon Dr. Sherlock's Book Intitled, The Case of the Allegiance Due To Soveraign Princes, Stated and Resolved, etc. Second Edition (London: Printed for J. Humphries, 1690).
} 
In this way, Connor used other voices in his text to either support his own assertions or relieve himself of any blame for assertions that may create controversy. Perhaps the best example of Connor's use of secondary voices within his text is Radziwill's comparison of Poland and England. This unnamed member of the Radziwill family tells the reader that Poland was less corrupt than England ${ }^{44}$ Connor becomes nothing more than the messenger.

Connor makes a point to show the reader how the Polish-Lithuanian Commonwealth and England are similar. Towards the end of the history, Connor includes a discussion he had with a member of the Radziwill family, a powerful magnate family in Lithuania. The youth was the son of Sobieski's sister and the head of the Radzwill family. The young noble to show how Poles believed they had certain similarities to England. Although he respects England the young Radziwil does see his Commonwealth as superior. In the conversation, the young noble mentions how, "Duke Radzivil told me that he had travell'd here in England when King James II was Corwn'd... He use'd to admire the Government of England, and to say that it was the best in Europe, except that of his own Country...."45 The Radzwill's reasons for Poland's superiority are, “...Constitution of Poland, was, that the King of England had a Power of turning People out of Employments, and the common People had the Benefit of Law, and could buy Estates as well as the greatest Noble-Man." ${ }^{46}$ The young noble thought Polish politics were more liberal.

\footnotetext{
${ }^{44}$ Connor. The IIistory of Poland, 200.

15 Connor. The History of Poland, 200.

${ }^{46}$ Connor. The History of Poland, 200.
} 
Young Radziwill 's comment helps to summarize Connor's major theme. The two kingdoms are similar, but Poland is perhaps more liberal and more tolerant than England. Connor uses the young noble to state how similar these two lands are. Radziwill explains to Connor that the two kingdoms are similar in government, but the Polish Commonwealth may be more liberal. Radzwill tells Connor that the Polish king has less power and the people have more mobility.

Connor already begins to let the reader know about the Commonwealth's struggle against the despotic French kings who "... [have] just reason to think that it would have been easier for [them] to manage his interests against the Empire with a king of Poland, who was likewise absolute, than it is now with one who entirely depends on the uncertain resolutions of a free parliament..." ${ }^{p 77}$ On page v, Connor refers to the corrupting influences of the "French Queens and French factions reigning amongst them during the four last Reigns..." Connor explains that for four years the French were attempting to support a stronger monarchy in Poland in order to expand French control over the parliament. According to Connor, these attempts were less than successful. Rather, the continual intrigues by the French crown, “... rendered [the Poles] more capable of knowing their own interest, and more wary than formerly of a Despotic Power." ${ }^{48}$ The author wishes to point out that the Poles become stronger through this struggle.

According to Connor, these nobles had real power over their king and Commonwealth. As mentioned, Connor makes a point to give his readers examples of both good and bad members of the Polish Clergy, Nobility and Monarchy. With these

\footnotetext{
t? Connor. The History of Poland, v.

18 Connor. The Ilistory of Poland, v .
} 
characterizations, Connor highlights for his English readership the problems of their own Commonwealth. Connor would use Poland as a mirror for reflecting England's shortcomings. Poland's enemies within would often have ties to the French monarchy. In the same way, Connor blamed Casimir Vasa's queen for the errors in his judgment, so Lehmberg blames Charles I's queen for many of the problems that would plague England. ${ }^{49}$

Being born to a family of Irish Catholics with ties to the O'Connor family, Connor seems to identify with the Commonwealth as an example for England. He describes the Cossacks as being treated in the same form as the Scots and Irish. He parallels the reigns of the Stuart Dynasty $(1603-1649,1660-1714)$ with those of the Vasa Dynasty (1587-1668) in Poland. The Vasas attempt to destroy Poland's parliament in the same way the Stuarts attempt to turn England despotic. When the parliament and the English people fought back, the Stuarts often retreated to France.$^{50}$ This flight to France will be a theme within Connor's history. Bad kings flee to France or Germany and good kings will outlive their enemies.

Throughout the seventeenth century the struggle between the Stuart Dynasty and the English Parliament became more acute. According to Lehmberg, from 1614 James I made do "... without Parliament for seven years...." until finances forced him to call another Parliament in $1621 .{ }^{51}$ Charles I continued to try and undermine the power of

\footnotetext{
${ }^{49}$ Lehmberg. The Peoples of the British Isles, 254.

5i) Lehmberg. The Peoples of the British Isles, 288.

51 Lehmberg. The Peoples of the British Isles, 236.
} 
Parliament from $1629-1640 .^{52}$ In an attempt to continue James' and Charles' program to take over parliament, Charles II and James II also attempted to rid themselves of the English Parliament. Charles II attempted to gain control over the English Parliament by attempting to enforce his own laws in 1679 and $1681 .{ }^{53}$ James II fought Parliament throughout his reign from 1685-1688. James II conspired with the Jesuits to overthrow Parliament and enforce Catholic despotism. According to Lehmberg, James II tried to control England through Catholic officials, "[h]is Catholicism became increasingly evident. He appointed Catholics, including a Jesuit Priest, to government posts and military commands, in violation of the Test Act." ${ }^{154}$ Although Connor was born an Irish Catholic he was still worried about what a Jesuit government would do to the English Commonwealth.

Charles II had managed to reign for several years without a parliament. Lehmberg reports that Charles II likewise "... the 'merry monarch' was surrounded by his frolicking court, untroubled by Parliament and unfriendly politicians...." ${ }^{55}$ In a similar fashion, the Vasas will be continually conspiring with French queens and Jesuit advisors. They will attempt to invade the Ukraine in the same way Cromwell would unleash his army upon Ireland or Scotland. ${ }^{56}$ The Vasas would attempt to capture the Protestant provinces of Sweden creating an escalation of violence and civil war in the same way Charles II

\footnotetext{
52 Lehmberg. The Peoples of the British Isles, 247.

${ }^{53}$ Lehmberg. The Peoples of the British Isles, 283-284.

${ }^{54}$ Lehmberg The Peoples of the British Isles, 285-286.

55 Lehmberg. The Peoples of the British 1sles, 284.

56 Lehmberg, The Peoples of the British Isles, 290-292.
} 
invaded the Netherlands, thus dragging England into a costly Third Dutch War. ${ }^{57}$ According to Lehmberg, this war would cause the English king to side with the French and the Parliament to side with the Dutch. This would be similar to the chaotic atmosphere during the Vasa wars with Sweden between 1617-1660 and the Vasa backed Cossack rebellion of $1648-1657$.

Connor entered Poland and found the Commonwealth he wished for England. Connor became captivated with the Commonwealth. While England was emerging as a parliament-driven monarchy by 1698 , the Poland Sobieski ruled had already been driven by elected kings and continual diets for over a century. England may have had an earlier constitution, but it had suffered from kings who only used the Parliament when they deemed necessary. In Poland, on the other hand, Connor found a parliament that only used kings when necessary.

According to Connor, in the Commonwealth, the king had no rights other than to lead the army and mediate between the nobles in the senate. ${ }^{58}$ In England, the kings were the ones who called the parliaments for most of the seventeenth century. The Stuarts' ability to dissolve Parliament was often used. When faced with a strong Parliament, Charles I dissolved itt in 1640. This was an action that would help destabilize his kingdom. In 1660, the diet referred to as the Long Parliament was considered unlawful, “... since it had not been summoned by king...." ${ }^{59}$ Many of the attempts to check the king's power were considered mute.

\footnotetext{
Lehmberg. The Peoples of the British Isles, 281-282.

58 Connor. The History of Poland, vii.

${ }^{59}$ Lehmberg. The Peoples of the British Isles, 274.
} 
In Poland the parliament had control over the government and continually banished those kings who would dare to counter their authority. ${ }^{610}$ According to Connor, Poland had been an elective government as far back as the mythic era. ${ }^{61}$ In this Catholicruled Commonwealth, there were no rules over who could be a senator. Gentry from all levels of society and all religions were able to debate over political issues in front of the king and the other senators. ${ }^{62}$

Magnates such as the O'Connor family would have had a place in the government, no matter what their ethnic or religious affiliation. Perhaps the most important aspect of this Commonwealth was the freedom of education. Under leaders such as Sobieski, all forms of sciences and philosophy were accepted. In Connor's moment of triumph over "...Father Vota, an ingenious Jesuit...." ${ }^{\text {"63 }}$ Sobieski backs the young physician. It was Sobieski who starts the argument in order to give a voice to the newly-developed forms of science. It is this Poland, the Poland that Connor describes, which brings into question the notion of a backward land to which even Connor's biographers refer. As one begins to read Connor's book, it is important to remember that Connor idealizes this land. His vision of Commonwealth is different than the one often presented in modern historiography.

Baruch Blumberg and Jean L. Blumberg’s essay “Bernard Connor (1666-1698):

\footnotetext{
6" Connor. The History of Poland, 207.

61 Connor. The IIistory of Poland, 7.

62 Connor. The History of Poland, 205.

${ }^{63}$ Connor, The History of Poland, 180-183.
} 
and His Contribution to the Pathology of Ankylosing Sodalities" ${ }^{\prime 64}$ praises Connor's ability to practice medicine while attempting to make Poland into a primitive distant land of mystery. The Blumbergs' essay emphasizes Halecki's theory mentioned in the introduction that there is a trend in historiography that falsely portrays the PolishLithuanian Commonwealth as a primitive and chaotic land in the east of Europe. The two authors focus on the sections of Connor's history that emphasize the differences between Poland and the rest of Europe. Their essay leaves out any reference to Connor's comparisons between Poland and England.

Connor's method of description can at times cause the reader to believe the author envisioned the Poles as primitive. There are several sections within the text where Connor uses language that seems to allude to an alien and primitive land. Connor's use of words such as "different and "unique" in his preface seem to make Poland a place that seems somehow alien to the cultural and political attitudes of the Atlantic powers known as Western Europe:

When [he] came first into this Nation, my chief Design was to converse with Physicians, and other Naturalists, to improve my Knowledge in the Practice of Physick, and in Natural History: But finding little here to satisfy my Curiosity in these Matters, that I might not lose my Labour in traveling into so remote a Country, I resolv'd to look into their Chronicles, to inform my self of the Origins of the Monarchy, of the Succession, and Remarkable Actions of all its Kings, of its Geography, and its Products, and to enquire to the Antient and Present Sate of that vast Kingdom. ${ }^{65}$

Connor mentions that he found little in Poland-Lithuania “... to satisfy my Curiosity in these Matters [Medicine]." He goes on to mention that he began to "...

\footnotetext{
${ }^{64}$ Blumberg. "Bernard Connor (1666-1698)," 363.

${ }^{65}$ Connor, The IIistory of Poland, 193-194.
} 
enquire to the Antient and Present Sate of that vast Kingdom." of context may seem to demonstrate the lack of education within the Commonwealth. The Blumbergs used this quote within their essay to back several other assertions about Poland. They take the above quote from the preface and combine it with other pieces of loose description in order to contrast Connor's exceptional ability in medicine with the rustic world he enters in search of a place to continue his studies. ${ }^{67}$

Poland becomes a place of curiosity without any real significance. The two authors explain, " $[\mathrm{I}] \mathrm{n}$ addition to formal historical material, he [Connor] included in the History many bizarre observations. He gives an account of the fire and serpent worship that existed in Lithuania before its conversion to Christianity in the fourteenth century and which still persisted in the remote sections of the country. “68 This description of Polish-Lithuanian pagan rituals is, however, not what Connor emphasizes in his preface or his book. He repeatedly mentions the way this kingdom was similar to England and how its parliamentary government was an important driving force for the Commonwealth's success.

\section{Poland in the European Context}

When taken out of context, certain sections of the history do seem to illustrate a wild and backward Poland in which Connor, however, was forced to live as a consequence of his views on anatomy. In his preface, he mentions how one of his reasons

${ }^{66}$ Connor, The History of Poland, 194.

6ๆ Blumberg. "Bernard Connor (1666-1698)," viii.

68 Blumberg. "Bernard Connor (1666-1698)," 353. 
for writing the history was in order to show the English readers the greatness of the Polish Parliament. “... for tho there are not so many Rarities to be seen, nor that, Conveniency of travelling as in most other Countries, yet they may observe the most remarkable Places in Poland, the peculiar form of Government, the Splendor of the Court, and the extraordinary Grandeur of the Nobility, who are not so barbarous nor so unpolished'd, as they are generally represented." ${ }^{\prime 4}$ The quote begins with a sentence that seems to portray Poland as a place of little worth. It has no great land marks or scenery. He also uses words such as "remarkable" and "peculiar" to describe certain elements of Polish culture." Although by themselves they seem unimportant, they can be used to show a backward kingdom if used in the wrong context.

Connor, however, gives significance to Poland. The overall context of this paragraph lets the reader know there is more to this history than just curiosities and barbarians. The quote demonstrates the value Connor places in the Commonwealth. It is not perhaps as beautiful as other lands, but it has something that other lands in the west do not have, a free parliament governed by a powerful senate. Connor even lets the reader know that the Poles were "... not so barbarous nor so unpolished" $d$, as they are generally represented. "'1 He seems to betray a bit of western bias when he continues to explain that one reason for their high culture was because the “... last sixty or seventy Years past, the Poles have taken a Humour to travel, and of late refined themselves extremely...."2

\footnotetext{
69 Connor. The History of Poland, v.

"Connor, The History of Poland, v.

${ }^{-1}$ Connor. The History of Poland, v.

7 Connor. The History of Poland, v.
} 
Although he was attempting to show how worldly the Poles were, he does it in such a fashion that it seems to link modernity with the western with western kingdoms like France. Yet most of the rest of the book seems to take a different view of France and "western" Europe.

Connor also points out differences in Polish dress and mannerisms. In Letter VI he discusses these differences in fashion. He explains that he would like to spend some time on the Poles' appearance. “... which because it is different from any other in Europe, I [Connor] thought an Account of it would not be unacceptable to your Lordship. They have their Hair cut round about their Ears like Monks, and wear furr'd Caps, large Whiskers, and no Neckcloths...."73 He discusses their clothing. Connor mentions the Polish “... long Coat [that] hangs down to their Heels, and a Wastcoat under that of the same length tied close about the Waste with a Girdle: Their Sleeves are extreme close, like those of Mariners, coming down to their Wrists, with a Flap on the back of the Hand...."4 It is in his description of the Polish clothing that the word "different" is mentioned. He explains to the reader that the Poles are different than other Europeans. The Poles have mannerisms that are unique to the Poles. They lack the frills and starch of European dress.

Connor still considers Poles to be a part of Europe. He does not refer to the Poles as different than Europeans. Rather he explains that their clothing “... is different from any other in Europe...."75 According to Connor Poland-Lithuania was still in Europe.

\footnotetext{
${ }^{-3}$ Connor. The History of Poland, 177.

${ }^{-4}$ Connor, The History of Poland, 177-178.

-5 Connor, The History of Poland, 177.
} 
Connor makes a point to let the reader know that though their clothing was different, "[t]his Dress looks extreme manly, particularly on Horseback, and is the most expensive of any that I [Connor] have seen in Europe...." Again they are included in Europe, and are Europeans. The Poles are not alien to the rest of Europe. They are not barbarians or uncouth. He believes that the Poles were more "manly." Connor saw the Polish tendency toward extravagancy combined with a sense of military prowess to be more masculine than the frilly and somewhat pampered look of other Europeans. The Poles have no neck clothes and cut their hair short. They carry pole axes and ride horses. These are men of wealth who still adhere to a warrior mentality. Connor's version of Poland was a land of extreme masculinity and wealth, mixed with a government that from the beginning strove to be free.

\section{Similarities Between Cossacks and the Irish and Scots}

Letter II includes a description of the Cossacks, a section of the Ukrainian population who would rebel against Polish rule. The Cossacks occupy an important place in this history. Connor compares the Cossacks to other tribal peoples who live on the borders of powerful empires. "At first they [the Cossacks] were Peasants that came from Russia and other neighboring Countries, settling in the islands of the River Boristhenes, and who afterwards spread all over Ukraina, and liv'd on Robbery; for they us'd to make Inroads into Tatary and Turky, plundere Trebisond and Sinope, and ravaged even up to the Gates of Constantinople." ${ }^{77}$ Connor depicts the Cossacks as a free people who do not shrink from a challenge. "They also us'd to pirate on the Black Sea, and have been very

\footnotetext{
${ }^{76}$ Connor. The History of Poland, 179.

Connor. The IIistory of Poland, 94.
} 
useful to the Poles when they were engage'd in War with the Infidels. I can compare 'em to no People better than to the Miquelets of Spain, or Highlanders of Scotland." ${ }^{-8} \mathrm{He}$ envisions the Cossacks as being similar to the Highlanders.

They are brave fighters and raiders. According to Connor the Cossacks are “... for the most part robust and strong, generous, and great Despisers of Covetousness, inconceivable Lovers of Liberty, and impatient under military Slavery: They are likewise indefatigable, bold and brave, but withal excessive Drunkards, treacherous Friends, and perdiious Enemies...." This love of freedom and hatred of slavery becomes apparent in the section of his history which discusses the Cossack revolution under the Vasa Dynasty.

The Cossacks are formed by peasants and nomads who refused to live under the control of Poland, Muscovy or the Ottomans. They are also a different religion from the rest of Poland and rebel when pushed to convert under the Vasas and their Jesuit clergy. ${ }^{81}$ This comparison of the Cossacks and Scottish is important due the struggle between the Poles and their Ukrainian subjects. The Cossacks want more rights in the Commonwealth in the same way that the Scots and Irish want more rights in the English empire. In Connor's history, the Poles have to contend with their brothers the Ukrainians in the same way the English must interact with the Scots and Irish. Connor's Poland is the continental equivalent to England in all its grandeur and weakness.

\footnotetext{
${ }^{-8}$ Connor. The History of Poland, 94.

${ }^{-9}$ Connor, The IIistory of Poland, 96.

${ }^{80}$ Connor. The History of Poland, 97.
} 
The Polish-Lithuanian Commonwealth as the Continental England

According to the British Short Title Catalog, Connor was not the first one to write and publish a text about Poland in the English language ${ }^{\mathrm{xl}}$ Connor was, however, one of the first English historians to write a book-length history that focused on Poland's origins to its most recent era, the seventeenth century.

There were other English histories that dealt with selected aspects of Polish history such as N. N.'s The History of the Late War With the Turks and An Account of the Defeat of Count Teckely and his Being Slain and Gilbert Eleazer's News From Poland.$^{82}$ The author attempted to give the reader a better understanding about the Cossack revolution that threatened to tear apart the Polish kingdom. Eleazer's essay is a reference to the Polish king's decision to revoke several "...privileges and liberties..." which the earlier parliaments had promised the Protestants in the Commonwealth. ${ }^{83}$ The anonymous author discussed the Cossacks and their revolution, but does not go into much depth about the ancient history of either the Cossacks or the Poles. He is more concerned with the outcome of a war that could alter the position of power in the east of Europe. The author explained how he wants to not only report the glorious exploits of the

\footnotetext{
81 English Short Title Catalogue Project. Early Printed Collections. The British Library

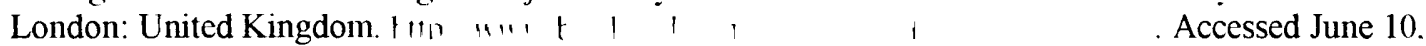
2003. In the list of book length Histories of Poland published during the seventeenth century, Connor seems to be the only book length text of English origin.

82 N. N, An .1ccount of The Defeat of Count Teckely and His Being Slain: Together With a Total Rout, Given to the Turkish Army by the Lnited Forces of the Christian Emperour and the King of Poland (London: Printed by E. Mallet, 1683) and Gilbert Eleazer, Newes from Poland. (London: Printed for Nathanael Butter), 1641.

${ }^{83}$ Eleazer, New'es from Poland, 8.
} 
Cossacks, but expand on the land which "...the Turks or Tartars should make their Inroads this Summer into Poland...." ${ }^{84}$ The author wanted to discuss the Ukraine and its impact on the area.

There were larger histories about Poland entering England, but they were often translated from other languages. Histories such as Pierre Chevalier's, $A$ Discourse of the Original, Country, Manners Original, Country, Manners, and Government of the Cossacks and King John Sobieski's memoirs, Polish Mamuscripts, or the Secret History of the Reign of John Sobieski, the III gave the English readership sources for a deeper understanding of the Polish kingdom, but they were not originally written to be read by the English speaker. ${ }^{85}$ Connor may have been one of the first English speakers who believed it was necessary to analyze the kingdom's beginning to its more recent state of affairs in the late seventeenth century.

Connor's The History of Poland is used to educate England about the best way to form a parliamentary government. The Commonwealth in Connor's history has many of the same promises and failings as England. Poland-Lithuania is similar to England in its strong focus on decentralized government. Connor repeatedly inserts discussions on the open-minded politics of the Commonwealth and the way the Polish people supported elective kingship and parliamentary government from the Poland's beginnings. One example of this type of argument is from the chapter on mythical Poland, "[t] ho, my

\footnotetext{
${ }^{84}$ N. N. An Account of The Defeat of Count Teckely and His Being Slain, 3.

85 Pierre Chevalier's, A Discourse of the Original, Country, Manners Original, Country, Manners, and Government of the Cossacks, With Another of the Precopian Tartars And the History of the I'ars of the Cossacks Against Poland (London: Printed by T. N., 1672) and Polish Manuscripts, or the Secret History of the Reign of John Sobieski, the III (London: Printed for T.N., 1683.
} 
Lord, this Lechus [mythical king of Poland] brought that People under a kind of Monarchical Government, yet neither he, nor any of his successors could ever so far prevail upon them [the people] as to make the Succession Hereditary.... ${ }^{186}$ His history portrays the Poles as a people who though their kings have tried at times to gain power over the government the people have continued to be "...Elective for above Eleven hundred years; always reserving a full Power and Authority to themselves, of choosing whom they pleas'd for their King...." ${ }^{\text {87 }}$ Connor's Poles refuse to live under a despotic government.

Connor finds Poland's greatest value to be its free parliament and the way that parliament helped to empower the people of the Polish-Lithuanian Commonwealth. He considers Poland to be a vast and powerful kingdom in Europe. Connor refers to the eastern sections of Poland as Russia and the Ukraine. ${ }^{88} \mathrm{He}$ also believes they control the whole of Prussia and have often fought for or against the might of the Holy Roman Empire. Connor repeatedly uses the Commonwealth's ability to survive the intrigues of France and Germany as examples of the parliament's staying power. "This Maxim has hitherto prov'd very beneficial to the Poles for enlarging their Country, and maintaining their Privileges; and might well have extended their Dominions beyond those of any State in Europe...." It is this "maxim" of decentralized government has helped Poland expand

\footnotetext{
${ }^{86}$ Connor. The History of Poland, 7.

$8^{7}$ Connor, The IIistory of Poland, 7.

${ }^{88}$ Connor, The History of Poland, 54-55, 97 and 161.

${ }^{89}$ Connor. The History of Poland, 7.
} 
its Commonwealth. Connor mentions that the Poland-Lithuanian Commonwealth could have become one of the greatest kingdoms in Europe if they only they:

... had their other Constitutions been as well grounded, or as exactly observed: For tho the Poles have been constantly molested by their Neighbours... yet by the prudent Conduct and Courage of their Kings, through a desire of gaining the Affection of their Subjects by serving their Country zealously, to the end their Fame and Merits might raise their Children to the Throne after their deaths... ${ }^{91}$

Any weakness the Commonwealth has is not due to the government's instability but external assaults and intrigues. Connor blames the problems of the Commonwealth on the French and Germans. The Poles are molested by the Holy Roman Empire from the tenth century through the twelfth century. Connor's history is filled with Piast and Jagiellonian rulers who either attempt to repulse or accept "German" interference within the kingdom. Throughout the sixteenth and seventeenth centuries, the French become an important antagonist toward Poland. The Holy Roman Empire still lurks in the shadows ever ready to push for a puppet king, but as in England, the French become the bigger threat. The rulers of the Holy Roman Empire tend to settle their differences through battle, whereas the French try to use foreign rulers to push for a system of despotism. In Connor's Poland an invasion can be repulsed, but a political manipulator is hard to counter. Often these French supporters are in the form of rulers or clergy, specifically the Jesuits. ${ }^{91}$

Connor elaborates on Poland's parliament. He focuses on how it keeps its power through the limitation of the king's duties and how the nobles have begun to forget the old political institutions that were once so important to their way of life. Connor

\footnotetext{
91) Connor. The IIistory of Poland, 8.

91 Connor, The History of Poland, 8.
} 
mentions how the Poles "...elect a Prince only to head the Army against the Invasion of Foreigners, and curb the turbulent Spirit of the Gentry, who think they are all equal amongst themselves, and their King but the first among his Equals." Connor mentions that though these nobles are concerned with equality, they are also becoming increasingly greedy. He blames this greed for the election of the Prince of Saxony. “...the Poles, who think themselves no longer bound by their Oath... give a new Precedence for those things they never practiced before, to exclude their own King's Sons and to elect a German Prince...."93 To Connor, this election was an affront to those who have died throughout Poland's history attempting to keep "German" monarchs off the Polish throne.

Connor explains to the reader that he consciously omitted many of the mythological aspects of the early Polish historians except “...the golden Tooth, the devouring Dragon, Popiel's being eaten by Rats, and some others, not with a design to make the Publick believe them, or that I beleiv'd 'em my self, but to shew how the ignorance of some, and the unfair Relations of others, have impos'd upon the World in all Ages." ${ }^{94}$ It becomes obvious that Connor's The History of Poland is being fueled by an agenda.

The preface already alerts the reader to a point Connor will repeat over and over again in his text. Connor wishes to point out the benefits of a free parliament. He finds these benefits to be evident in the Polish government. Connor writes The History of Poland in order to show the English speakers who persecuted him for his beliefs and

\footnotetext{
92 Connor. The IIistory of Poland, vii.

${ }^{3}$ Connor. The History of Poland, vii.

94 Connor. The History of Poland, viii-ix.
} 
ethnic origins that there were stronger commonwealths out there in Europe that did not worry about such petty things. Being a member of a high-ranking Irish family, he forgives the Polish-Lithuanian Commonwealth for the way they treated their serfs.

Judging by his pedigree he probably agreed to a certain extent with the Polish nobility. Moreover, the Poles safeguarded a decentralized government that allowed power to be shared by more people than England. Connor saw in Poland-Lithuania a political and cultural model that could be used in his own kingdom to relax many of the restrictive elements within England. His preface is constructed in order to support his claims within the text by building up an aura of scientific respectability. Connor does this in the hopes of demonstrating that Poland is a major power in Europe and an important example for other kingdoms attempting to fight off what he considers the despotic powers in Europe. Although Connor uses words that may seem to be alluding to some sort of "difference" between Poland and the rest of Europe he is actually making it a powerful part of Europe. This trend toward holding Poland up as an example of liberal-minded progressive politics also supports Wolff and Todorova's theories that the backward eastern part of Europe was a construct of a later century in order to fit its new vision of progressive politics. In the end Connor is searching for a Commonwealth and found it in Poland-Lithuania. 
Chapter III. The Polish-Lithuanian Commonwealth

Bernard Connor's History of Poland is a morality play which uses the nobility, prelates and kings of Poland in order to give the reader a better understanding of the virtues of a free parliament. Like most modern historians of Poland, Connor divides his history into four classes of political leadership. ${ }^{1}$ The book begins with the mythical dynasties of pagan Poland, then discusses the Piast Dynasty that first embraced Christianity, moves on to the Jagiellonian Dynasty and ends with the elected kings. ${ }^{2}$ In each period, Connor uses the nobility and religious factions within Poland as forces of stability or corruption which correct or impede the ruling dynasty. The kings are divided into good and bad monarchs. The positive rulers can keep Poland stable, while the negative rulers often lose control over both the people and the kingdom. Connor uses his depictions of the noble, religious and royal elements of the Commonwealth not only to give the reader examples of those traits that might cause the kingdom to progress as a parliament or bow to despotism, but also to provide a series of traits that will emphasize Sobieski's character as a statesman, warrior and king. These traits also give the English readers a better understanding of those hurdles England must face in its quest for parliamentary development and political equality.

\section{Connor's Religious Leaders}

The religious figures in Connor's book are briefly mentioned throughout the history. Religion in Connor's text is a force that helps or hinders the progress of the

\footnotetext{
I In modern historiography the dynasties tend to be separated into the Piast. Jagiellonian. and elective. This is common in such histories as Zamoyski`s The Polish IIay. Halecki`s History of Poland and Davies` God's Plavground.

2 Connor, The History of Poland, 10.
} 
Commonwealth. Before the sixteenth and seventeenth centuries Connor tends to focus on religious figures and religious movements in terms of how they furthered the spread of Christianity in Poland and Lithuania. Connor's perception of the religious forces that helped to create Poland changes as the Commonwealth passes from the mythic kingdom of the sixth century to the confused republic of the seventeenth century. The troubles between Catholics, Protestants and Orthodox groups within the Commonwealth cause Connor to pick and choose heroes and villains.

Although Connor converted to Anglicanism, his text tends to be less sympathetic to the Protestant forces in Poland ${ }^{3}$ This tendency to portray the Protestant political leaders as troublemakers may betray the level of Connor's religious change to the Church of England. The Catholic factions are often portrayed as diplomatic and tolerant toward the Protestants. The Lutherans tend to impede the advances of the Commonwealth by conspiring with enemy forces such as the Germans or French. In Chapter IV, the "Germans" play the role of antagonist throughout most of the history. The Holy Roman Emperors continually invade Poland either to gain the throne for themselves or to promote a loyal faction. These "Germans" often aided the rebellious Protestants or attempted to claim the Baltic in the form of a Crusade. Connor's Poles and Lithuanians continually push these armies back only to have their descendants elect a noble from Saxony to the throne after King Sobieski's death. Connor will continue to discuss this last election at the end of the history.

Connor's discussion of the Habsburg archduke Maximilian III who lived from 1558 to 1618 is an example of the "German despot" and the rebellious Protestants use of

\footnotetext{
${ }^{3}$ Connor. The History of Poland, 119.
} 
such outside powers. The section on Maximilian III implies that those Protestants who followed the teachings of the religious dissenter Martin Luther were attempting to back the would-be ruler over a Swedish candidate named Sigismund Vasa. According to Connor, Maximilian's campaign for the throne of Poland-Lithuania was drawn out into three major battles. However, Zamoyski includes two attempts by Maximilian to get the crown of Poland. Maximilian attempts to take the throne in 1587 during the election and a second time in 1590 after Sigismund Vasa is elected by majority vote. ${ }^{4}$

Connor informs the reader that the series of invasions ended in disaster for the Habsburg and his supporters. Connor explains that after Maximilian's first march on the Commonwealth, " $[t]$ he Lutherans still insisted upon those Demands they had formerly made, which were fain to be granted them, because Maximilian was again ready to take the Field, notwithstanding his last Defeat." "In the history these religious figures tend to impede the progress of the senate and the king by their continual conspiracies and foreign alliances. They conspire to gain more say in the government. The Protestant groups within the text often use those forces within Poland to get what they want. In Connor's history the Protestants are continually attempting to court outside forces in order to gain control of the senate. When the Protestant factions are unable to force a change through their allies within the nobility and Catholic clergy they rally behind the newest European force to invade the Commonwealth. These invading forces are usually German, French or Swedish.

${ }^{4}$ Zamovski. The Polish IIay, 131.

${ }^{5}$ Connor. The IIistory of Poland, 109. 
These continual intrigues give them some form of leverage within the Commonwealth. Connor writes, "[t] he Lutherans contended so high for their share in the Government, that for Peace sake they had more granted them than the antient Laws of the Kingdom allow'd: For in this Assembly their Party was so strong, that they not only obtain'd Toleration, but also perpetual Liberty of Conscience." Connor repeatedly mentions the Commonwealth's ability to promote laws that enforced religious tolerance between all groups within the Commonwealth. Friedrich, Stone, Davies, Zamoyski, and Tazbur` all make mention of this trend towards religious tolerance within the Commonwealth. Connor picks up on this issue and emphasizes it in order to show his English readers that a parliament can be a strong political power while allowing religious toleration. This aspect of Polish politics will be repeated throughout the history, especially in passages discussing the positive rulers of Poland.

Connor's tone changes from defending the Commonwealth's free thinking to charging it with fanning the flames of revolution when he begins his discussion about the dispute between the Catholic and Orthodox people who live there. Although both groups wanted more representation within the Polish senate, Connor seems to be more sympathetic to the Orthodox. The rulers are often forced to humor the Lutherans in order to keep the peace.

The only period in the book when the Catholics seem intolerant of other religions and ethnic groups is during the reigns of Vladislaus and Casimir Vasa. The Vasas and

"Connor, The History of Poland, 101-102.

Stone. The Polish-Lithuanian State, 120. Zamoyski. The Polish Way, 105-108, Davies. God's Plavground 199-200, Tazbir, "The Fate of Polish Protestantism in the Seventeenth Century." 99-121.

Friedrich. The Other Prussia. 71-74. 
their allies among the nobility back the Jesuits, who embody French Catholicism. In return, this helps to alienate the Orthodox Cossacks. The historians Pollard, Friedrich and Tazburs, like Connor, claim that the Jesuits were the cause for the Commonwealth's decline ${ }^{8}$ All four historians blame the Jesuits for the religious alienation of the Cossacks. Connor takes this argument one step further and argues that the Jesuits were helping to promote French politics. ${ }^{9}$

The Catholics as a whole, though, are not the villains. While the Jesuits and the Vasa kings attempt to force a more despotic form of government on the Commonwealth, bishops and prelates of older Catholic organizations attempt to stop them. Catholics from earlier groups tend to be less militant and more willing to compromise. The older Catholic orders have been tied to Polish history for a greater time and are often less likely to push for a strong central government. Connor's Jesuits gain support from the Vasa Dynasty in the same way the Stuart Dynasty attempted to use them to enforce their will over a parliamentary political system. This order is more aggressive and intent on uniting the gentry under the king.

In Connor's history, religious figures such as the Bishop of Kiovia stand up to the foreign influence of the Vasa-backed Jesuit forces that represent French despotism. The bishop sides with the Protestants in order to keep the French Catholics from taking over the political sphere of the Commonwealth. Connor writes, "This Retreat of Casimir among the Jesuits, gave occasion to the Bishop of Kiovia to labour at his Exclusion, in

\footnotetext{
${ }^{8}$ Pollard. The Jesuits in Poland, 58-81, Friedrich, The Other Prussia. 60-67 and Tazbir. "The Fate of Polish Protestantism in the Seventeenth Century," 215-217.

${ }^{9}$ Connor, The History of Poland, 112-113 and 126-127.
} 
which he was zealously assisted by the Protestants, who mortally hated that Society. This bishop likewise imagin'd he had got the major part of the Gentry on his side, who seem'd also dissatisfied with the Jesuits." "Knowing that many of the Polish nobles are either sympathetic or in agreement with the Protestant minorities within the Commonwealth, the Bishop of Kiovia attempts to get their aid in forcing Casimir out of office.

Connor seems to identify with the Orthodox Cossacks due to his tendency to compare them to other marginalized peoples such as the Highlanders. This sympathy is partially due to the way in which the Ukraine seems to be governed by nobles who have a different religious ideology than those they rule. Connor explains, "[t] heir Religion is generally the Greek Perswasion, which they reciev'd in the Year 942, under the Reign of Vlodomir Prince of Russia; yet the greatest part of the Gentry posess either the Roman or Reform'd Religions. These Greek Principles extend all over Muscovy, Moldavia, Valachia, Turkey and Persia." According to Connor there was a division between the Ukrainian lower classes and the nobility. This division only helps to distance the gentry from the common people within the Ukraine. Connor mentions how many of these Ukrainian nobles were, “...Great Men of Poland [who] having purchas'd diverse Estates in Ukrania, thought their Revenues might be considerably augmented, if the Privileges of the Cossacks were but reduc' $d$ to a narrower Compass..."12 The Cossacks become the defenders of this lower class. In Connor's history the Cossacks are not trying to destroy the Commonwealth, but hoping for some form of representation within the senate. These

\footnotetext{
${ }^{10}$ Connor, The History of Poland, 126-127.

11 Connor. The History of Poland, 97.

12 Connor. The History of Poland, 122
} 
Ukrainian soldiers are attempting to stop the same form of forced colonization and subjugation that Coxe had supported in his essay.

Connor blames the nobles who, “... prevail'd upon their King Vladislaus to send General Konicepoliski to reduce them." ${ }^{13}$ This nobility is made up of faceless members of the Commonwealth. Although those sections of the history referring to the Cossack revolution tend to portray the Polish nobility as corrupt, throughout most of the history the nobility seem to be freedom-loving men who will not allow corruption to destroy their Commonwealth. Since Connor was born to Irish parents with ties to the O' Connor family, he may have seen similarities between Bogdan's war and the struggle of the Irish. Although the Cossacks are compared to the Scots, they still face the same problems that plagued the Irish. This section of the book is the first time Connor seems to break with his usual affection towards the Poles as being the upholders of parliamentary government.

The Nobles of The Commonwealth

The Commonwealth's nobility in Connor's history tend to be divided into heroic statesmen who stay loyal to the king and the senate or willful villains who put their own dreams before the senate. An example of a noble who personifies the negative qualities of the senate is Christopher Zborowski. He is depicted as a member of a powerful family of the late sixteenth century who attempted to control Polish politics by manipulating the new king Stephan Batori (1576 to 1586). The Zborowski family helped to get Batori elected and therefore expected him to do their bidding in Polish politics. Connor points

${ }^{13}$ Connor, The History of Poland, 122. 
out how a Samuel Zborowski “... employ'd All his Interest for Batori, for at the time of the Election he writ to several of his Relations and Friends to Vote for that Prince; but it being the Temper of the Polanders never to think themselves sufficiently recompens'd after they have done a Service, Batori, tho he sought all he could to oblige that Family, yet could not keep them from proving his most inveterate Enemies..." ${ }^{14}$ It ends badly for the Zborowski family. Samuel is sentenced to death in Transylvania while Christopher Zborowski is banished from the kingdom.

After Batori's death Zborowski returns at the head of an army composed of Germans, Frenchmen and Lutherans. Connor goes on to explain that, ' $[t]$ he time of the Election being come, Christopher Zborowski, who was banish'd during Batori's Reign, and now recall'd by the Power of the Lutherans, appear'd at the head of 500 French, with as many Germans and Lutherans as amounted to near 10000 Men." As Connor mentions, the Zborowskis are an example of the Poles who never seem to be sufficiently satisfied with what they are given by the king.

Zborowskis' return to Poland gives Connor a chance to introduce an example of the positive noble. This nobleman is John Zamoski ${ }^{16}$ In the character of Zamoski, the reader is given a portrait of the heroic noble. Zamoski is the virtuous noble who defends the Commonwealth from the evils that try to destroy it. He is charged with the care of the Commonwealth. ${ }^{17}$ He must defend the kingdom from the Zborowski family, who attempt

${ }^{14}$ Connor, The History of Poland, 88-89.

15 Connor, The History of Poland, 102.

16 Connor. The History of Poland, 103.

$1^{1-}$ Connor, The History of Poland, 108. 
to rally Protestant factions to the side of the Habsburg-archduke. In his attempt to make Zamoski a great hero and defender of the Commonwealth, Connor emphasizes how "Zamoski was also at the head of a considerable number of Troops, which, tho they were fewer than those of the opposite Party, yet were they much better disciplin'd; with these he encamp'd within two Miles of Warsaw, and entrench'd himself within Lines of Circulation." ${ }^{" 18}$ Zamoski and his army are examples of those senators and gentry who were determined to put the Commonwealth and its freedom before their own happiness. They are outnumbered but better trained and more valiant in their resistance. Zamoski and his soldiers receive victory for their diligence.

After defeating Zborowski, Zamoski continues to defend against Emperor Maximilian and his Lutheran followers. The Protestants who had backed Maximilian's claim to Polish-Lithuania continue to conspire with the Habsburg prince. Zborowski's wickedness stretches beyond his own desires. In Connor's history, Zborowski's allies continue to plague the Commonwealth even after he is suppressed ${ }^{19}$ Zamoski manages to beat the Protestants and fend off Maximilian's invasion. For his ability on the battlefield, " $[t]$ he Diet, before they separated, charg'd Zamoski with the Care of the Commonwealth." ${ }^{21}$ He does not enjoy his victory for long before he is called on again to defend the Commonwealth from a second invasion the archduke Maximilian in 1588 . Zamoski is once again told to defend the Commonwealth against the army of the

\footnotetext{
18 Connor. The History of Poland, 102.

19 Connor. The History of Poland, 105.

2n Connor, The History of Poland, 108.
} 
Habsburgs. According to Connor, Zamoski succeeds in his battle against the Empire to the west and manages to take Maximilian prisoner.

Connor uses the episode not only to demonstrate Zamoski's heroics in the field, but his kindness to those he takes prisoner. When Maximilian is defeated and taken captive, “....Zamoski treated his Prisoner very honorably, which gain'd so much upon the Arch-Duke, that he afterwards stood Godfather to one of his Children."21 Thus, Connor portrays Zamoski as both the heroic noble and the generous conqueror. He is a man that can stay his hand once victorious and the enemy is asking for quarter.

\section{The Kings of Poland}

Perhaps the most overshadowing characters of Connor's history are those who are raised to the throne of Poland. The chronology of Poland's kings is both important in the formation of chapters and the major factor in his vision of the eternal parliament. ${ }^{22}$ Connor focuses chiefly on how the king and the parliament interact with each other. According to Connor, the parliament gives strength to the kingdom. It is with the parliament in mind that the great kings are able to push the kingdom into a position of greater power in the hopes of the senate's favor ${ }^{23}$ Likewise a bad king tends to impede or ignore the senate and thus cause chaos within the Commonwealth.

The first group of rulers are the mythic leaders of Poland. Connor mentions how these mythic rulers "... met with the same Fate with most other Countries, that is, to be little Known from its Minority: For when this Monarchy was first founded by Lechus,

\footnotetext{
21 Connor, The History of Poland, 110.

22 Connor. The History of Poland, 7.

23 Connor. The History of Poland, 8.
} 
there were no Learned Men to hand down to Posterity by their Writings the true State thereof from its Infancy...." Connor accepts that the supposed origins of Poland's ruling dynasties are not always based in fact. Connor indicates in his preface that he uses sections of the mythology of Poland's past "... only to shew how the ignorance of some and the unfair Relations of others, have impos'd upon the world in all Ages." ${ }^{25}$ The chapter on the mythic dynasty is more allegorical than historic. It is an example of Connor's desire to turn Poland's history into a template for other struggling parliamentary governments. Connor introduces a basic system of comparison in his chapter on mythic Poland which continues throughout the history. He puts the majority of the rulers into two categories, the virtuous or the decadent. Connor's rulers demonstrate the positive or negative elements in the monarchy itself. They demonstrate what a good or bad ruler could do for the Commonwealth.

The second chapter discusses the rise of the Piasts and the Jagiellonians. Letter III spans the beginning of historic Poland and continues into the sixteenth century. The chapter focuses on the origins of the free parliament and the people that helped it continue for so long. Connor opens up his chapter with a brief discussion of how the Piast family ruled for 600 years in Poland proper and continued to rule in Silesia until 1675. ${ }^{26}$ He explains that although the family ruled for so long, they were elected to the throne

\footnotetext{
${ }^{24}$ Connor. The History of Poland, 3.

25 Connor. The History of Poland, ix.

26 Connor, The History of Poland, 22.
} 
based on the merit of their family's deeds. ${ }^{27}$ To Connor the Polish parliament was almost instinctive.

Although historians such as Norman Davies and Adam Zamoyski do not refer to the Piast kings as elective, Connor mentions that even the Piasts had a semi-elective quality to their rule ${ }^{28}$ Connor's discussion of Piast rulers like Boleslaus are used to both give the reader an understanding of the early rulers and to demonstrate how the proud people and the early elective government gave the early Poles powerful rulers.

The Piasts

The section on the twelfth century Piast King Boleslaus III, also known as the Wry-Mouth or crooked face, gives the reader an example of the heroic origins of the Polish kingdom. Boleslaus was elected in 1103 and nicknamed the Wry-Mouth because of his crooked smile. Connor writes about the Piast king's battles with his brother and his war with Henry V (1106-1125) of Germany. Boleslaus becomes symbolic of the devout ruler who expanded the kingdom while not bowing to the temptation of foreign despots. ${ }^{29}$ Henry V attempts to bribe him with gold but is rebuked by the Wry-Mouth and his ambassador for believing that the Polish leader would succumb to such greed. Connor recounts how Henry took ,"Scarbicus the Ambassador to see his Treasure, he [Emperor Henry V] told him, that that (pointing to his Gold) would bring the Poles to what Terms he pleas'd." Annoyed by the Emperor's presumption that he could buy Polish submission, “... Scarbicus being highly affronted, took off a Gold Ring from his Finger,

\footnotetext{
${ }^{27}$ Connor, The History of Poland, 8.

28 Connor, The History of Poland, 27 and 30.

29 Connor. The History of Poland, 31.
} 
and throwing it into the Treasury...." He then tells the Emperor on behalf of his king, “...I do not question but the Polish Iron (meaning their swords) will prove as good Metal as the German Gold. Which said, he immediately took his leave, and returning to his Master [Boleslaus the Wry-Mouth], acquainted him with his Negotiation; which the haughty Pole highly resenting, resolv'd to hazard a Battle...." ${ }^{30}$ Boleslaus' advisor returns to Poland to inform the king of Henry's bribe and the inpending war.

Boleslaus and Henry V meet at a place called the Dog's-field. Connor describes the battle and how the Wry-Mouth forced the Emperor to sue for Peace. To Connor, Boleslaus is one of several kings who characterized the perfect Polish monarch. Connor's Boleslaus is brave and proud. He does not bend to greed and worries about the well being of his subjects. Connor ends his biography of the Wry-Mouth with a description of the heroic kings abilities. Connor explains how Boleslaus “... was of an undaunted Spirit, a great despiser of Danger, and no less an observer of Truth and Right; very liberal and generous upon the smallest Occassions, and moreover endued with singular Clemency and Modesty. He was further very ambitious of Glory, but at the same time no Enemy to Peace, tho he is said to have been train'd up to War from his very Cradle." ${ }^{31}$ Boleslaus sets the pace for many of the kings to come. According to Connor Boleslaus, like Zamoski, is a brave, honest soldier with an understanding about the need for peace. A king can be ambitious and war-like as long as it helps to further a acceptance of free thought within the Commonwealth and protect Poland from foreign intrigues. Boleslaus represents the Polish desire to create a strong political power in Europe while also

\footnotetext{
30. Connor, The History of Poland, 32.

31 Connor, The Ilistory of Poland, 33.
} 
keeping foreign powers from taking it over. The strength of the Piasts will become important for Connor when the nobles of the seventeenth century decide to ignore Sobieski's Polish dynasty for the "German" dynasty of the Saxons.

Boleslaus' children drag the kingdom through a period of civil war that lasts for about two hundred years. During this period of civil war the crusading armies of the Teutonic Knights are invited into Prussia. Connor, like most pro-Polish historians including Davies, Zamoyski and Stone, discusses the problems this army would cause for the later Piasts and Jagiellonian dynasties. ${ }^{32}$ These crusaders are often blamed for creating a earthly kingdom in eastern Prussia and the intrigues that lead to the conquest of Pomerania which severed the region from the Polish crown until the battle of Grunwald in 1410 .

The Piasts and their turbulent dynasty ends with the rule of Casimir III, or Casimir the Great in $1370 .{ }^{33}$ Connor's history portrays Casimir the Great as both a lawgiver and a warrior. Connor credits Casimir with bringing order to the kingdom that had been devastated by Boleslaus's children. ${ }^{34} \mathrm{He}$ is also the last Piast to rule Poland; once Casimir dies he is replaced by the Anjou and then the Jagiello Dynasties. ${ }^{35}$ Connor describes Casimir as a "... a very lewd Prince, but withal exceeding Liberal and Just: $\mathrm{He}$ kept a Jewish Concubine, at whose request he granted great Privileges to that People: He gains so well the Opinion and Affection of his Subjects, that he was stil'd the Father of

\footnotetext{
32. Stone, The Polish-Lithuanian State, 95-96, Zamoyski. The Polish IIav. 46-52, Davies, God's Plavground, 120-123.

33 Connor, The History of Poland, 54.

${ }^{34}$ Connor. The History of Poland, 56.

35 Connor. The History of Poland, 54.
} 
the Poor." ${ }^{\text {3t, }}$ Casimir is both the lawmaker and the benevolent ruler. He is one of Connor's good Piasts. He will be one of the men against whom Sobieski will be measured.

Connor credits Casimir with the conquest of Russia and Masovia. "The Poles had several times conquere'd Russia, but it was never enjoy'd peaceably till Casimir's time; who having had better success than any of his Predecessors, annex'd it as a province to the Crown of Poland. The Province of Masovia was likewise conquer'd by him, and annex'd to the Crown." ${ }^{37}$ Connor considers the Ruthenians to be Russian. Historically they were supposedly descended from the Kievian Rus, but they were later drawn closer to the Ukraine. The Ruthenians were ruled by a member of the Piast family. When he died, Casimir began a long war with the Lithuanians over the absent throne. Although Casimir's conquests were very important for the way they helped to draw Poland closer to Lithuanian and Ukrainian politics, they were not as drastic as Connor makes them. Casimir conquered what is referred to as Ruthenia in modern historiography, and Masovia was willed back to him by the last Piast who ruled there ${ }^{38}$

The author wishes to create a great man to conclude the Piast Dynasty. He must be a great soldier and ruler. As the ruler a king should bring stability to his people. Casimir is credited with implementing the Magburg laws, a series of religious law codes that the Teutonic Knights used to rule their lands. Connor explains that, "[t] he Poles had never hitherto any written Laws, and but very few made till Casimir began to make Institutions, name judges, create Magistrates, build Forts, and establish a better

${ }^{36}$ Connor, The History of Poland, 55.

$3^{\top}$ Connor. The History of Poland, 54.

${ }^{38}$ Davies. God's Playground, 95-96. 
Oeconomy in the Kingdom than any Prince before him. ${ }^{39}$ Like Connor, Casimir tries to come up with a perfect model to give Polish law structure. They both wish to give their nations legal stability in the hopes of creating a just kingdom. According to Connor, "[t] he Laws and Constitutions of the Teutonic Knights seem'd very rational and political to him, having had a sensible Experience of good Government of this Order for a considerable time...." Connor's version of Casimir the Great is similar to Davies' and Zamoyski's depictions of this ruler who helped to build up Polish infrastructure. ${ }^{41}$

Under Casimir, cities are built for Jewish and German minorities. Poland becomes both militarily strong and politically accepting. Connor explains how Casmir “...was surnam' $d$ the Great (being the only Person that had that Title among the Polish Princes) not because he had gain'd a great many Victories, but by reason of the many beautiful Structures and Fortresses he had built, as likewise of the many beneficial Laws and Constitutions which he had made." " Casimir's ability to reinforce Poland's infrastructure and increase its territory becomes important for Connor's description about the late King Sobieski. Sobieski and Casimir are both native kings attempting to repair the kingdom and find a way to ease Poland's pains and political stress. The difference is that Casimir helps to get the Anjou Dynasty on the throne while Sobieski tries to find a way to make his sons more appealing to the senate. Casimir is the last of his dynasty.

\footnotetext{
${ }^{39}$ Connor. The History of Poland, 54.

40 Connor. The IIistory of Poland, 54.

${ }^{41}$ Zamoyski. The Polish Hay, 38 and Davies, God's Playground, 96-98.

42 Connor. The History of Poland, 56.
} 
After Casimir the kingdom will elect a new dynasty and follow a new political organization. Casimir becomes important because he takes a kingdom that was battered by previous kings and gives it strength. Just as Boleslaus becomes important for his inability to bend to greed, Casimir becomes an example of how a ruler can save the Commonwealth.

Although Connor spends some time on the rulers from the Anjou Dynasty and their rule over Poland, it is the Jagiello family that becomes the major focus of the second half of the chapter. Stone explains that this dynasty would begin the Commonwealth and its trend towards an elective kingship. ${ }^{43}$ Zamoyski mentions that this union with Lithuania would help Poland by giving it more troops but would also draw the Poles into the political turmoil of the eastern part of Europe ${ }^{44}$ Under the Jagiello Dynasty, Poland prospers as a Commonwealth.

The Jagiellonians

Connor's usual positive/negative comparison seems to change during this section of the book. The Jagiellonians are given heroic status as the once-pagan family that change their ways and begin to expand Poland. Connor, Friedrich, Stone, Davies and Zamoyski all seem to argue for a similar point when he refers to the way this new dynasty helped to end the Teutonic Order's control over the Baltic. ${ }^{45}$ The Order was finally subjugated and the political power of the kingdom began to spread over other

\footnotetext{
${ }^{43}$ Stone. The Polish-Lithuanian State, 62-66.

${ }^{44}$ Zamoyski. The Polish Way, 44-45.

45 Friedrich. The Other Prussia, 4-5, Davies, God's Playground 120-123, Zamoyski. The Polish IIay. 4652 and Stone. The Polish-Lithuanian State, 95-96.
} 
lands, especially Hungary and Bohemia. Throughout the history, this order of German crusaders schemed and plotted ways to conquer or plunder the Poles and their neighbors.

According to Connor, the Order was originally supposed to help the Poles fend off the Prussians, but they soon become an extension of what Connor calls the "German Empire." Once Poland and Lithuania are united under the first Jagiello, Uladislaus V, the two kingdoms begin a war with the Order. This sporadic war lasts from Uladislaus Jagiello (1386-1434) till Casimir IV's reign (1447-1492). Casimir IV also becomes important to Polish due to his ability to place his children in key positions of authority within Central Europe. According to Connor Casimir IV had “... four Sons, whereof Vladislaus was first chosen King of Bohemia, and afterwards of Hungary; for this last Kingdom, after their King's Death, had entreated Casimir to send one of his Sons to reign over them." ${ }^{46}$ The Jagiellonian Dynasty helps to bring Poland into the wider politics of Europe.

This dynasty's most important feature for Connor's history lies in its role as unifiers of a new form of Polish government. Connor explains that it was under these rulers that the kingdom becomes a Commonwealth. The new government will eventually evolve into the constitution-based government that Connor adored. Connor's Jagiellos are powerful leaders who wish to unite the Lithuanians, Poles, Prussians and Russians into a large Commonwealth formed from several provinces tied together by a senate of representatives raised from the nobility within each province. Their election gives the nobility in Poland more power over the king. In Poland heretics and pagans find safety

${ }^{46}$ Connor. The History of Poland, 65. 
from persecution. Uladislaus V, “... first promis'd to embrace the Christian Religion with all his Country, who were before Pagans: Next to unite Lithuania to Poland, during his time, under the same form of Government; and lastly, that in case his Male Race fail'd it should for ever after be annex'd to that Kingdom. Hereupon Jaggello was baptize'd, and takes upon him the Name of Uladislaus V ..." ${ }^{47}$ In Connor's history all the Jagiellonians are powerful leaders, yet the strongest members are Casimir (1446-1492) and Sigismund August (1548-1572). Under Casimir's reign the Commonwealth is able to expand into central Europe and finally humble the Teutonic Knights. Sigismund shows the Jagiellonians' ability to understand the need for political and religious freedom.

The character of Casimir Jagiello best symbolizes this family. He came to power in 1446 after stability had been fostered in the kingdom. The once powerful Teutonic Order had been humbled but not conquered. Education was becoming important and the arts were supported. Through the use of colleges, such as the Jagiellonian University in Krakow, Casimir is able to enlighten his people and make the Commonwealth intellectually prosperous. ${ }^{48}$ Connor credits Casimir with the final conquest of the Order. Connor asserts that the Prussians who had tired of the Order's control and came to Casimir for help. ${ }^{49}$ Casimir raised an army of Lithuanians and Poles and invaded the territories under Teutonic rule. He accepts the Prussians-homage and plea for support.

Casimir takes on the form of liberator. Although he loses the first battle with the Order, he rallies his men and continues to push forward into the Order's territory. Casimir

\footnotetext{
47 Connor, The History of Poland, 59.

48 Connor. The History of Poland, 64.

${ }^{49}$ Connor, The IIistory of Poland, 65-66.
} 
was able to rally his troops and "...call'd a Diet, and prevail'd so far upon the Gentry as to grant him half their Yearly Revenues to carry on the War against the Teutonic Order by which means after a long and obstinate Dispute, he at last obliged 'em to accept Articles of Peace...."5) Casimir carries the day and forces the Order to give up western Prussia. He returns the cities of Pomerania, Culm, and Michalow to Poland. Connor also gives Casimir the credit for forcing the Great Master into giving eastern Prussia over as a vassal of the Commonwealth. According to Connor, Casimir V accepts this truce “...only on condition that their Great Master for ever after should be Prince and Senator of Poland, and take Oath of Fidelity to the King." ${ }^{\text {51 }}$ Casimir does not destroy the Teutonic Order but makes them part of the Crown's lands. The Grand Master becomes a senator, not a prisoner.

Connor tells his reader that Casimir was also the Jagiellonian who built on Casimir's reforms by including the Diet of Provinces, which gave legal representation to provincial courts and curbed the power of the senate. "In the time of this King Casimir, the Deputies of the Provinces first appear'd at the Diet: For before the King and Senators had the supreme Power of making Laws." 52 This addition is important due to its ability to expand on the present checks and balances. At this point in the history, Connor's Poland is a land with a senate or Sejm, a provincial diet or Sejmiki, and a king who rules a constitutional monarchy.

\footnotetext{
50 Connor, The History of Poland, 64.

${ }^{51}$ Connor. The History of Poland, 64.

52 Connor, The History of Poland, 65.
} 
As education, literature, and art begin to become more important, Latin is used by all members of society. Connor explains that “... Casimir being much ashame'd of [he was that only the Clergy knew Latin], publicly commanded all his Officers forthwith to set about the Study of that Language; from which time the Poles have continu'd great Proficients therein, nay, beyond any other Nation whatsoever." ${ }^{\varsigma 3}$ The emergence of both political tolerance and education are embodied under the last Jagiello, Sigismund II Augustus, who began his reign in 1548. Under Sigismund the Lutherans become a power in Poland. They, like other groups, are tolerated for the good of the kingdom. "About this time Martin Luther's Doctrine came to be known in these parts, and most of the Citizens of Dantzic embrac'd it; for which at first the King was very severe with them, but at length, fearing that to preserve their Religion they might side with the Teutonic Order against him, he granted them Liberty of Consience." ${ }^{\$ 4}$ In Connor's book, Sigismund understands that the salvation of the Commonwealth was more important than the desire to keep one religion.

Under the Jagiellonian government the king and the senate could not persecute one group of Poles without bringing into question the constitution as it stood by the rule of Sigismund. Under Sigismund, religious freedom is an important aspect of the Commonwealth's design. ${ }^{55}$ Connor also spends time discussing the creation of a band of Satirists who call themselves "[t] he Commonwealth of Babina." The Commonwealth of Babina was not a province, but a band of satirists who roamed around the

53 Connor, The History of Poland, 65.

${ }^{54}$ Connor. The History of Poland, 70.

55 Connor, The History of Poland, 78-79. 
Commonwealth criticizing Poland's weaknesses in the form of jests and witty caricatures. Connor mentions how "[i] n Sigismund's time flourish'd the jocular Commonwealth of Babina, consisting of several merry Gentlemen of Lublin, who met together at a place call'd Babin to exercise their Wits upon all occasions." ${ }^{16}$ The interaction between Sigismund and the Commonwealth of Babin showed that the Commonwealth fostered a place to comment on the weaknesses of the kingdom.

Connor goes into detail about Sigismund's encounter with this group of satirists. There is a feeling of mutual respect. Their interaction with the king supports the image of Sigismund as the liberal ruler who accepts free speech and open debate. "The Commonwealth of Babina" is said to criticize religion and senatorial power, but they understood the value of a kind and benevolent leader. Under Sigismund's kind leadership this troop of satirists "... in a little time they reform'd most of the Abuses and Indecorums crept into the Government of Poland, and prov'd that the force of Satyr is of no less benefit than that of Oratory." When Sigismund asked who their king was, the leader of the "Commonwealth of Babina" told him that they had none. The leader of the "Commonwealth of Babina" replied that, "[f] ar be it from us, most Serene Monarch, that we should make choice of any other King while your Majesty is living." ${ }^{\prime \prime}$ The satirists respect the king for his kind rule and accept him as their leader. He is the one political figure that they have no desire to impersonate.

The period of Jagiellonian rule is depicted as a time of great freedom. The period, however, cannot continue forever, and it begins to change when Sigismund dies. Upon

\footnotetext{
${ }^{56}$ Connor. The History of Poland, 79.

57 Connor, The IIistory of Poland, 80-81.
} 
Sigismund's death, Poland reverts into an elective monarchy. The elective government is not necessarily a negative development. Connor and Stone both point out that the elective dynasties are a continuation of politics started under the Jagiellonian Commonwealth. ${ }^{5 x}$ Under Sigismund, the Commonwealth was expanded into Livonia and enhanced by the rule of a benevolent king.

\section{The Elected Dynasties}

The next chapter of Connor's book focuses on the final Polish dynasty. The chapter discussing the elective kings begins with the election of Henry of Valios (15551589). He did not sit long on the throne. Connor explains that the king returned to France in order to become the Henry III of France. The next king to be elected was from a Transylvanian family. Stephan Batori came to power in 1576.

It was the confusing politics of this election that led to the clashes between Zamoski and Zborowa. Connor explains how Batori continued to expand on Poland's political and intellectual strengths. ${ }^{59} \mathrm{He}$ is a strong character with unbending morals. Many of the conspiracies brought into play during Batori's reign were due to his unwillingness to show favor toward certain nobles during his rule.

Connor informs his readers that under Batori's rule the Lutherans achieve a greater political voice in politics. He also implemented new reforms in the military and political institutions in an attempt to bring the Commonwealth up to the same level as the other armies of Europe. According to Connor, "[h] e was a prudent and circumspect Prince, courageous, and just even to Severity. He not only enlarg'd his Dominions, but

58 Stone, The Polish-Lithuanian State, 62-63.

59 Connor, The IIistory of Poland. 
also settled a better order in 'em than any before him; and I have heard the Poles speak of him with the greatest Respect and Veneration." ${ }^{\prime(x)}$ It was his decision to give the Cossacks in the Ukraine more military power and a political voice within the Commonwealth. They served the Commonwealth as a buffer zone against the Tartars and provided infantry and light horsemen.

According to Connor, it was under Batori that the Ukrainian section of the Commonwealth was given more power and provincial rule. He, “”.. order'd 'em Officers and General; and moreover, gave 'em the Town of Techtimoravia upon the River Boristhenes, which they made a Magazine, as also the Place of Residence for their Governours, to be a Bulwark against the Irruptions of the Tartars...He endow'd 'em likewise with many Privilages; for all which they afterwards did him considerable Services." ${ }^{61}$ Once again Connor gives his English readers an example of a king who is brave like Boleslaus and Casimir, yet liberal in his political regulations like Sigismund. Batori grants the Cossacks a place in the Polish-Lithuanian Commonwealth. He does not allow his judgment to be clouded by biases against a group of people who tend to be somewhat individualistic and alien to the rest of Poland.

Connor writes that Batori attempted to have one of his nephews crowned in order to carry on the legacy, but the senate refused to follow his request fearing despotism. ${ }^{62}$ They did not wish to give precedence for the beginning of a new dynasty continually commanding the throne. The next dynasty to be elected would test the very freedoms that

\footnotetext{
${ }^{60}$ Connor. The History of Poland, 100.

${ }^{61}$ Connor, The History of Poland, 94.

62 Connor. The History of Poland, 100.
} 
the senate feared losing under the Batori family. Connor alludes to the Polish tendency to ignore a capable but powerful dynasty in the hopes of a weaker one. Yet this new dynasty would be less capable and perhaps more destructive. It would mark a turning point in Connor's history.

The first member of the Vasa Dynasty to be elected was Sigismund. It was during Sigismund's election that Zamoski fought so hard to keep the Habsburgs from seizing the throne. It was after Sigismund's election that these same nobles become divided over the war with Sweden ${ }^{63}$ Unlike Batori, Sigismund wanted to continue his rule in Sweden and claim the right to Poland's crown due to his tie to Jagiellonians. Connor explains that, through a series of events, the crown of Sweden would fall to another member of the Swedish family. ${ }^{64}$ When Sigismund attempted to retrieve it, he began a war with Sweden that would last through most of Letter III and end in the loss of Livonia, east Prussia, and the eastern provinces of the Ukraine.

After Sigismund's death his son Vladislaus took the throne. The Poles decided to choose Vladislaus rather than face a worse tyrant. Vladislaus, however, turned out to be that tyrant. Connor's book shows how Vladislaus is given the dubious label as the one who started the civil war between the Polish-Lithuanian Commonwealth and its southern provinces in the Ukraine. According to Connor, Vladislaus begins the bloody war by revoking the privileges given to the Cossacks under Batori's rule. He holds a diet in which the Poles and the king decide, “...that all their [the Cossacks'] former Priviliges, together with the Fortress of Tectimoravia, granted them by King Stephen, should be

\footnotetext{
${ }^{63}$ Connor. The History of Poland, 113.

${ }^{64}$ Connor, The IIistory of Poland, 112-113
} 
taken from them, and a new Body of Militia setled there in their stead. ".65 Yet this could be due to the apathy of the king. Connor asserts that Vladislaus gives into the demands of the greedier elements within the nobility who wish to colonize the Ukraine. Connor saw the Ukrainians were being colonized in the same way the English began to colonize Ireland and Scotland.

Connor views the Cossacks as heroes attempting to avenge an injustice. These Ukrainian rebels become a reflection of the Scots and Irish who defend their freedom “... with great bravery; who yet nevertheless promis'd to be faithful to the Crown of Poland, provided their antient Privileges might be continu'd to them; which the Poles readily agreed to, but however never prerforme'd: Nay, treated several of them very ill; for among other oppressive Methods, they took from them som of their Greek Churches. ${ }^{" 66}$ Bogdan is portrayed as a noble who is unjustly treated by the Poles and in his time of despair leads a revolution. Connor explains that “...the Cosacks recover'd in some measure under thir General Bogdan Chmielinski, who having been justly enraged by Kaminski [a powerful Polish noble] ravishing his Wife, and afterwards murdering both her and her Son, resolv'd on some Expedient to revenge this Affront, and rid his Country of the Tyranny of the Polish Government." ${ }^{\text {67 }}$ It is this section that seems to designate a decline in the moral fiber of the senate and a sinister air to the throne. Connor seems to believe that this weakness is largely due to outside forces that are at work trying

\footnotetext{
Connor. The History of Poland, 123.

66 Connor. The History of Poland, 123.

6. Connor. The History of Poland, 123.
} 
to corrupt the nobility and king who were already becoming greedy and interested in things beyond the welfare of the Commonwealth.

Vladislaus is only the second stage in Connor's depiction of the tragic period of civil crisis brought on during the seventeenth century. The greed and conspiracies of Sigismund and Vladislaus come to a climax under the rule of Sigismund's other son Casimir Vasa. Casimir's reign is filled with problems from the beginning. During Casimir's rule, the Bishop of Kiovia attempts to incite a rebellion against the king because of his Jesuit upbringing. According to Connor even the Catholics in Poland were worried about Casimir getting the throne.

Connor's history maintains that the foreign power most interested in ruining Poland is France. Although Poland had to continually fend off Habsburg advances, it is Casimir's French queen that causes the greatest problem for the Commonwealth. ${ }^{6 *}$ Casimir was educated in the Jesuit schools of France and decided on a French queen as his bride ${ }^{69}$ Connor blames the French bride for causing many of the troubles that were to befall the Commonwealth in the following pages. "He [Casimir] marry' $d$, by the Pope's Dispensation, the Queen-Dowager Mary Ludovica his Brother's Queen. She being a French Lady, and medling too much with Affairs of State, perhaps with design to promote a successor of her own Country, is thought to have contributed in great measure towards the Troubles which afterwards ensu'd."' She wanted her husband to become a despot like the French king.

\footnotetext{
${ }^{68}$ Connor. The History of Poland, 128.

n9 Connor, The History of Poland, 126.

Connor, The History of Poland, 128.
} 
According to Bernard Connor, Casimir does what he can to foment revolution within the Commonwealth in order to better serve this purpose. He hoped to thin out the Polish nobility by getting them embroiled in a war against the Cossacks. Casimir hoped too use the tension between the Cossacks and the Poles to foster a war that would humble the nobles and bring the Senate under his control. With the senate broken, he could gain more power. Connor explains how Casimir placed all the blame on the nobility, “... the Cosacks sent to the King to know if this had been done by his Majesty's Order; which being aswer'd in the Negative, and moreover, that the Nobility had done it to be reveng'd on them for the frequent Damages they had done them...."1 He places the blame on the nobility in order to encite this civil war.

Connor's Casimir Vasa wanted to use the Cossacks to exterminate the nobles. Connor continues his discussion of Casimir's plot by telling the reader that he helped to instigate the Cossacks war when he told them that if they wanted rights they would have to claim them:

This appear' $d$ unquestionable by a private Letter intercepted, sent under Casimir's own hand to Chemielinski and Doroczinko, Generals of the Cosacks army, whereby he invited them to make War against himself for not having been redress' $d$ in the Greivences they had sustain'd under the Jews, the Noblemens Stewards in the Ukraine; by which means he gave them occasion to deliver themselves from the Polish Slavery, as they continue to this day."

Casimir's plot succeeds too well and soon the Cossacks are slaughtering Polish armies and using foreign power to aid them. The Cossacks became too strong and a minor uprising turned into a civil war. The Cossacks first ask Tartar forces to help bolster

\footnotetext{
${ }^{\prime}$ Connor, The History of Poland, 130.

${ }^{2}$ Connor, The IIistory of Poland, 134-135.
} 
their armies. Casimir is forced to head an army into the Ukraine or lose the kingdom. The rebellion became to powerful and soon "...they [the Cossacks] immediately, in conjunction with the Tartars, fell into Poland with the greatest Fury imaginable. Against these the King went in Person at the Head of the Nobility, and defeated them in Battle."’3 The Poles are able to win the first part of this Cossack rebellion.

In the end, Casimir had to humble himself and side with the nobility lest he lose the entire Commonwealth. A large army of Poles invade the northern Ukraine, temporarily halting the Cossacks. The Cossacks soon find an ally in the Tsar of Muscovy and return to their rebellion. With the support of the Muscovites, the Cossacks are able to once more march on Poland. In the end, the Poles are forced to make a treaty with the Russians which ends in a partition of the Ukraine. Connor notes that the Poles are able to route the Russians, but they are invaded by Charles Gustavus and have to make a treaty with the Russians in order to free up troops and gain an ally. ${ }^{74}$

Charles's army is able to sweep the Polish armies from the field and claim the throne of Poland. Connor goes into length about how Casimir flees Poland and the Prussians use this war to make a push for independence. It is only after Poland agrees to grant a union between Brandenburg and East Prussia that the armies of Ducal Prussia attempt to counter Swedish conquests. ${ }^{-5}$ Connor continues the reoccurring theme of the outnumbered Polish loyalists who rally to defend their Commonwealth against all odds.

\footnotetext{
${ }^{73}$ Connor, The History of Poland, 130.

${ }^{-4}$ Connor. The History of Poland, 130.

${ }^{-5}$ Connor. The History of Poland, 132.
} 
With the help of a league of neighboring kingdoms a heroic noble, general Czarneski is able to rally those still loyal to the throne to repel the Swedes and their Polish allies.

Connor refers to the great effort the Poles and their allies in Europe perform in order to pushes the Swedes out of the Commonwealth. This European army push the Swedes out through a series of military maneuvers. Connor writes, "[ $t]$ he Danes likewise made a considerable Diversion on their part by attacking Sweden. The Muscovites came upon Livonia, and the Emperour sent Troops to succour the Poles; whereupon, by Assitance of the Brandenburgers and Tartars, and the prudent Conduct of General [Stephan] Czarneski, the Polish Nobility in six Months time restor'd Casimir to his Throne. ${ }^{, 6}$ In the end, the Polish nobility are able to save the Commonwealth from the invading Swedish armies. During the seventeenth century other nations are still willing to come to the Commonwealths defence and help repel the Swedes.

The sporadic war for the crown of Sweden ends badly for both the Vasas and the Poles. Under the rule of Casimir the Poles lose sections of the Ukraine and the Baltic. Connor notes at the end of his chapter on Casimir that his wickedness does not end with the backfired attempts at gaining power over Poland and Sweden. He attempts to seize control of Poland with the use of mercenaries from "Germany," or the Holy Roman Empire. "Casimir, after having routed the Swedes, rais'd an Army of about 30000 Germans, under pretence of being reveng'd on the Tartars for detaining several Polish prisoners, which he had betray'd himself, the better to curb his Subjects." The nobles figure out what he plans to do with these soldiers and force Casimir to disband his army.

\footnotetext{
${ }^{76}$ Connor, The History of Poland, 131.

Connor, The Ilistory of Poland, 132.
} 
The nobles, “... having discover'd his private Design, which was to render himself Despotic, rais'd an Army likewise, and attack'd that of the King with so good Success, that he entirely routed it, took its general, a Frenchman, Prisoner, and quickly oblig' $d$ the King to disband his German Forces." "Again the potential despot uses "German" and French troops to do his bidding. The Poles, however, have had enough of his plotting and refuse to give him anymore power.

Casimir, seeing his power disappearing and the nobles growing more and more aggressive, attempts his most daring intrigue. He embezzles the Polish treasury. Connor explains how Casimir performs this crime by using re-minted Copper coins to pay “... the Publick for what they brought in, as likewise the Arrears of the Army, but kept all the Gold and Silver, which he afterwards privately remitted into France, and soon follow'd himself, whereby he beggar'd the Nation; for which the Poles condemn him even to this day." With this act, he not only betrays his French sympathies but also ruins Poland financially in his flight. The Poles lose sections of their Commonwealth and suffer financially from the extended wars of the Vasa crown. Yet they still exist as a free parliament.

Although their first election after the Vasa's results in a weak king, the second election resulted in their finest ruler. This new king was John III Sobieski. He is portrayed as a ruler who seems to best represents all that is great in Poland. It is in Letters III and IV Connor will construct the history of a leader that embodied all those great leaders that were discussed throughout the rest of the book. After giving the reader

\footnotetext{
${ }^{-8}$ Connor. The History of Poland, 133.

-9 Connor The IIistory of Poland 134-135
} 
examples of good and bad rulers, heroic and wicked nobles and loyal and disloyal religious figures, Connor gives the reader the greatest of all three. Letter III of the history ends with the election of Michael Wiesnowski (1669-1673). In reality this section of the chapter focuses on the rise of Sobieski. Letters III and IV create a vision of Sobieski that embodies the pride and greed of the bad kings and nobles combined with the heroics and kind rule of the good kings and nobles. In essence Sobieski is Poland. He is all of the potential and failures of the Commonwealth. 
Connor's history openly attacks the English political system with his depiction of King John III Sobieski's rise to power through his ability to rise in status through a political system where anyone who can vote can also be a leader regardless of fortune, religion and ethnic origin. Connor begins Letter III with a description of the late king Michael Wiesnowski and his short time on the throne. He reduces the discussion on Michael to brief passages that focus on how he was a weak leader who may have been poisoned. According to Connor, some of the Poles believed that he was "... suppos' $d$ to have been poison'd by a French-man at Zamoisk...." Connor spends most of this chapter discussing John III Sobieski's rise to power. He uses Sobieski as the ultimate statesman who demonstrates aspects of both the good and bad elements of the nobility, clerics and royalty. Sobieski will begin as a bad noble only interested in personal honor and promotion and rise above this character trait to become the embodiment of men like Zamoski, Boleslaus the Wry-Mouth, Casimir and Sigismund Jagiello and the Bishop of Koivia. Sobieski's rise to power will demonstrate the freedom of movement that the petty nobility and burgher classes had within the Commonwealth.

Connor understood that the Commonwealth continued to keep their lower classes in serfdom throughout the seventeenth century. Although the serfs had little freedom under Sobieski‘s rule, Connor does not see him as a despot. Connor will also bring into question the next king of Poland, Augustus II (1697-1764), and the nobility's lack of aggressive defense against the outside forces that helped to carry the election. Yet,

1 Connor. The History of Poland, 149. 
Connor is not ready to write the Commonwealth off the political map of Europe. It still has some benefits to the world in the example it sets for other kingdoms with its political prestige and liberal policies.

\section{The Epiphany}

At first Sobieski is the bad noble. Like Zborowski, Sobieski attempts to get the new king dethroned because of a slight to his personal and family honor. ${ }^{2}$ In Letter III Sobieski's continually intrigued against Michael, but has a change of heart after the Ottoman army invades Podolia.

Connor's version of Sobieski became angry when Michael rejected Sobieski's present. Sobieski presents the king “... with a Coach and six Horses to comply with the Custom only, for it must be understood Sobieski was his Enemy; the King by the Persuasions of his haughty Mother refus'd the Present, which the General greatly resented sought all manner of ways to be reveng'd on him..."3 Once rebuked, Sobieski becomes the new king's worst enemy. Connor mentions how Sobieski “... frequently caball' $d$ with the Gentry assembled in parliament against him..." The early Sobieski tends to rally other nobles against the king. He undermines the king and the senate in order to exact his revenge. Sobieski was another noble who seemed to be a challenge to the politics of the Commonwealth.

Although he is initially an example of the negative noble, Sobieski soon becomes the positive one after the Ottoman invasion of 1620 . His character changes once Poland is

\footnotetext{
2 Connor. The IIistory of Poland, 146.

${ }^{3}$ Connor. The History of Poland, 146-147.

${ }^{4}$ Connor, The History of Poland, 147.
} 
invaded by the Ottomans. The Ottoman invasion shook up the Commonwealth enough that “...General Sobieski, and the rest of the caballing Party being asham'd of this dishonorable Treaty, came to a better Understanding among themselves, and sided with the King to recover what had been lost." ${ }^{\text {"5 }}$ His attitude changes quickly when Sobieski realizes that the Commonwealth is threatened by a Cossack and Ottoman army. Sobieski is forced to accept his place in Polish history when the Ottomans capture Podlia. While Sobieski plotted against Michael his fellow soldiers were left to die at Caminiec. ${ }^{6}$ Sobieski has to choose between letting Poland suffer a new invasion and the loss of territory or swallow his pride and do his duty to the Commonwealth. Connor writes about how the "... [a] rmies of Poland and Lithuania marched directly towards Podolia to retake it, that of the Kingdom being commanded by General Sobieski, and the other of the Dutchy [Grand Dutchy of Lithuania] by General Patz."' Sobieski and Patz lead the army to victory over the invading Ottoman armies.

After Poland is invaded by the Ottomans, Sobieski becomes much more like Zamoski, the great general of the early seventeenth century. Connor tells the reader that Sobieski even married Zamoski's widow sometime after Michael's death. ${ }^{8}$ As the Zamoski figure, Sobieski helps to lead an army into Podolia in an attempt to repulse the Ottomans. It is during the battle near Caminiec that Sobieski embodies both the heroics of Boleslaus the Wry-Mouth and Casimir Jagiello. Connor explains how “... [g] enerals [

\footnotetext{
5 Connor. The History of Poland, 148.

${ }^{6}$ Connor, The History of Poland, 147.

Connor. The History of Poland, 148.

${ }^{8}$ Connor, The History of Poland 150.
} 
Sobieski and Patz] soon obtain'd a signal Victory over te Turks near Kochim five Leagues from Caminiec, by the treachery of the Moldavians and Valachians, who never hitherto signaliz'd themselves but perfidiously, which prov'd very advantageous to the Poles, who were then in want of every thing but Courage. ${ }^{\prime 9}$ It was this ability to raise the Polish spirit that helped him get elected.

Sobieski is ready to fight to the death against the army of an invading empire in the same way Boleslaus the Wry-Mouth resisted an army from the Holy Roman Empire in 1109. When the Valachians and Moldavians join his side he becomes the heroic liberator, embodied by Casimir Jagiello. Connor's version of Sobieski embodies the heroics of the Jagiellonian ruler who fought so hard against the Teutonic Knights in an attempt to rid the Prussians, Poles and Lithuanians of their heavy handed control of the Baltic. Sobieski's battle, however, will take him to the Black Sea and the Balkans.

The Politicians

Letter IV focuses on Sobieski and his daughter. Connor used this chapter to show how Sobieski was the great Polish statesman. Connor focused on Sobieski's ability to rise from a lowly petty noble to the king of Poland. He spends the greater part of that rule defending the Commonwealth and liberating other European powers that are threatened by the Ottomans. ${ }^{10}$ Connor goes further into Sobieski's ability to rule justly and his reinstitution of those forms of freedom that the Poles lost under the Vasa kings. The reader will notice four major sides to the statesman: the politician, the general, the liberal ruler and the pious hero. It is through these four sides of Sobieski that Connor

\footnotetext{
${ }^{9}$ Connor. The History of Poland, 148.

${ }^{10}$ Connor. The IIistory of Poland. 173-175.
} 
demonstrates the Polish king's ability to become a great king like the rulers of the Piast and Jagiellonian dynasties.

According to Connor's history, Sobieski becomes one of the greatest leaders of Poland-Lithuania. Connor explains that as a king Sobieski “... so prudently manag'd the Interest of the wisest Republick in the World in in a long lingering War against the Ottoman Empire." Connor, however, believed the greatest aspect of Sobieski's life was his ability to go from petty gentry to a wise and honorable king. Connor believed Sobieski was an example of what was possible in the Commonwealth. He managed to advance through his role as a husband, a soldier and a senator. Connor lets his readers know that "John Sobieski, my Lord, is not so much to be esteem'd for his memorable Exploits after his Election..." He goes on to explain that his greatest assets were “... his Merits, and wise Conduct by which he advanc' $d$ himself from a private Gentelman of an indifferent Fortune, and nothing at all related to any of the former Kings, through all the Posts of the Army to the Crown of Poland, notwithstanding the several powerful Factions which appear'd against him..." "I2 Connor thinks that Sobieski had to be an amazing statesman to be able to overcome the overly competitive political atmosphere of the Polish bureaucracy.

Connor explains that Sobieski's parents were social climbers in their own right. According to Connor, Sobieski's father advanced his own political career through more bureaucratic means. He was the Castellan of Krakow and became the Ambassador to the

11 Connor. The History of Poland, 153.

12 Connor, The IIistory of Poland, 154. 
Ottomans in $1621{ }^{13}$ Sobieski's mother was the daughter of a military hero, Stanislaus Zolkiewski, who lost his life at the battle of Cicora in 1620 and spent his earlier years as Grand Chancellor and Grand General of the Crown under the Vasa Dynasty. ${ }^{14}$

Sobieski's parents did their best to give their son a well-rounded education. When he was a young man, his father sent him to travel and study in France. While there, Sobieski's father bought him a position as Captain of Horse. After France, Sobieski traveled to England, "Germany" and Italy in order to better understand other Europeans' philosophy and tactics. ${ }^{15}$ This experience made him as politically cunning as Casimir the Great and Stephan Batori. Once Sobieski returned to Poland, he married Zomoski's widow and began to climb the ranks within Casimir Vasa's military. In Connor's history, Sobieski is an example of a politician who does his best to position himself into the political spotlight while seeming less aggressive than the other candidates.

\section{A Heated Election}

Connor continues to promote Sobieski as the great statesman. Sobieski's ability to climb the political ladder emphasizes the freedom of the Polish parliament. His ability to rise in prestige and gain the throne shows the Commonwealth's fluid political landscape. Yet, Connor sees Sobieski's ability to survive the next election and become the next king of Poland as perhaps Sobieski's greatest triumph. ${ }^{16}$ Connor explains that he pushed the Ottomans out of Podolia and ended the tribute that the Ottoman's had demanded during

\footnotetext{
13 Connor, The History of Poland, 16.3

${ }^{14}$ Connor, The History of Poland, 163.

15 Connor. The History of Poland, 164.

${ }^{16}$ Connor, The History of Poland,
} 
Michael's reign. The military background helps to propel him in his political climb.

During the elections that followed Michael's death, Sobieski backs an unknown French candidate. Sobieski seems to be following in the footsteps of Zbrowoski by backing a monarch from one of Poland's two antagonists. Connor lets the reader know, however, that Sobieski was actually working to get himself elected. "General Sobieski propose' $d$ the French Prince, but in reality work'd under-hande for himself." "^ He is using this campaign to promote himself while pretending to support a foreign candidate.

It is during Sobieski's election that Connor gives the reader a bit more insight into the complexities of the seventeenth-century Commonwealth. While Sobieski backs the mysterious French candidate, the other hero of the Podolia campaign, Patz, supported Louis XIV Duke of Lorraine (1664-1668, 1670-1697). Muscovy, the Holy Roman Empire and Brandenburg Prussia attempt to sway the election. Sobieski and Patz are both heroes and therefore command the most votes. Connor describes the impact these two nobles had on the senate. He writes about how none of the nobles "... had any thing like the Train of the two Marshals of the Crown and of Lithuania: their Parties seem'd too numerous to assist at a Diet where there is so much Freedom as in that of Poland."18 These two war heroes represent the Polish magnates that so many historians blame for the fall of the Commonwealth.

Patz realizes that Sobieski is attempting to get himself elected and tries to throw his weight behind the Duke of Lorraine. These two heroes met in the political level of the Commonwealth driven by a specific goal “... Sobieski apparently sought the Crown from

\footnotetext{
17 Connor. The History of Poland, 157.

18 Connor. The IIistory of Poland, 157.
} 
himself, and Patz, his Design was to hinder him from obtaining it." ${ }^{19}$ The election heats up more once Sobieski is able to get the senate to make him an official candidate for the election. The senators continually negotiate with each other to try to gain the greatest benefits out of the newly elected king, while also attempting to keep foreign powers from deciding the election. In the end, the Russian provinces in the Commonwealth decide to place their votes with the Sobieski's camp giving Sobieski the largest voting block. The Russians Connor mentions are actually Ruthenian and Belarussian. He explains that these “... Russia [ns] being influence'd by what their Palatin had said, immediately declared for Sobieski, who was a Native of their Province, and all the rest of Poland soon followed their Example...." The other provinces follow Russia's example. This gives Sobieski a lead in the election.

Connor explains that in a last-ditch effort to block Sobieski's election, Patz protests the election on constitutional grounds. Patz tells the senate that the election was unconstitutional because Sobieski did not carry the election with a majority vote. Upset about Sobieski's ability to carry the election Patz “... immediately enters protest against this Election, alledging that it was against the Costitution of the Kingdom for any King to be chosen without the common Consent...."21 The rest of the nobles push Sobieski's election forward, causing Patz to leave the election in anger. Although Patz is ignored, the attempt to use constitutional means in in order to derail Sobieski's election shows the amount of power the Poles gave to their constitutions.

\footnotetext{
19 Connor, The IIistory of Poland, 158.

2 Connor, The History of Poland, 161.

${ }^{21}$ Connor, The History of Poland, 162.
} 
Connor's detail on the Sobieski election demonstrates just how deeply imbedded the idea of free parliament and majority vote had become. The election is very confusing with various factions making and breaking agreements in order to elect a king with similar political views. The senators' and candidates' continual alliances seem to be an example of the confusing political world of the Commonwealth, yet this shifting of alliances also demonstrates how fluid this free parliament was. The candidates are politicians who shift their views and change their platforms in order to get the majority vote. These confusing elections are a testament to the Commonwealth's emphasis on majority and minority rule.

\section{A Merciful Warrior}

Sobieski continues to be John Zamoski or Casimir Jagiello in his ability to be generous with his enemies. As a resurrected Zamoski, Sobieski creates a trust fund for Michael's widow. ${ }^{22}$ Perhaps the best example of Sobieski's ability to be kind to the defeated enemy is during Connor's depiction of Sobieski's siege of Zytchin. After raising the siege of Vienna in 1683 , Connor's version of Sobieski pursues the Ottoman army into the Balkans. ${ }^{23}$ Sobieski was able to break the resistance of the Ottoman fortress Zytchin, but is noble enough to grant the valiant defenders the ability to give up and retreat to Buda without molestation. Knowing they were beaten “ $\ldots$ the Turks hung out a white Flag, and the Commander in Chief, with two others, came out and begg'd his Majesty to permit them to march to Buda; which was granted..." ${ }^{24} \mathrm{He}$ will not fight an

\footnotetext{
22 Connor, The IIistory of Poland, 165.

23 Connor. The History of Poland, 177.

24 Connor. The History of Poland, 176.
} 
army under a flag of peace Connor's Sobieski is the merciful knight, yet he is also kind and liberal toward his subjects. Connor makes Sobieski into all that was great with the Jagiellonians by using his description of the king's court.

Connor shows Sobieski's similarities to Casimir Jagiello. He gives the reader examples of Sobieski's similarities to Sigismund Jagiello. Connor mentions the way the nobles who are often respectful to him outside the senate are quite critical of his views in the senate. "And I admir'd to see the Persons that abus'd him in the Parliament-house, and spoke to him with all freedom when he sat on the Throne, pay him so great a Submission ad Respect every-where else. But the Liberty of a Member of that Parliament is such, that he can speak what he thinks, and think what he pleases, without any Fear of the King." 25 These senators are allowed to protest and disagree with the king in the Senate without fearing any retribution.

The Progressive Thinker

Connor continues to promote Sobieski's ability to govern kindly with his discussion of the king's support of the new trends in science and medicine. It is during Letter IV that Connor repeats a moment at the Polish court where he was allowed to best a Jesuit priest in a debate over the study of the body and soul in medicine, free will and the meaning of death. By including the debate with the Jesuit cleric, Connor shows not only his own brilliance, but the open minded rule of Sobieski who allows the same open debate that Sigismund Jagiello promoted during the reign of "The Babina Commonwealth." Sobieski intentionally stirs up debate between the members of his

25 Connor, The History of Poland, 205. 
court, “....he delighted much in Natural History, and in all the parts of Physick; he us'd to reprimand the Clergy for not admitting into the university and schools the Modern philosophy..." ${ }^{26}$ Sobieski wanted to modernize how the Poles think and view the world around them. According to Connor the king “... love'd to hear Persons discourse of those Matters, and had a particular Talent to set People about him very artfully by the Ears, that by their Disputes he might be diverted, as hapned often in my time...."27 This diversion is in essence showing how forward thinking the leaders of the Commonwealth could be.

Connor makes himself seem humble and unwilling to debate the new scientific philosophy. Yet he is urged on by Sobieski. Connor explains how “...once when [he] was undersigned concerned my self; the King being at Dinner, and having the Bishops of Posnania, Plosko, Vilna, and other Divines about him, particularly Father Vota, an ingenious Jesuit, the King ask'd me in Latin, What part of the Body I thought the Soul was in?" ${ }^{28}$ Sobieski deliberately pits Connor against the Jesuit in order to expose the court to the newest scientific philosophy and how it compares to the older vision of the world. The three-page debate also shows how Sobieski promoted the Scientific Revolution. This becomes important when Connor is attacked in England for trying to use the same scientific methods he discussed in Poland. Sobieski's court comes out seeming more enlightened than the kingdoms in the west. In this way, he is similar to Sigismund Jagiello, who promoted intellectual interaction and enjoyed debate. Connor mentions that because of Sobieski's earlier education he spoke several languages and became a very

\footnotetext{
${ }^{26}$ Connor. The IIistory of Poland, 180.

`- Connor. The History of Poland, 182.

28 Connor, The History of Poland, 183.
} 
accessible and civil leader who did his best not only to promote open debate but also education and more tolerant political positions.

Sobieski swears to protect the rights of the various religious groups within his kingdom. Connor mentions how Sobieski, as with other kings of Poland, “... at his Coronation promises to protect four Religions, the Roman, which he must seem to be of himself, the Protestant, the Greek, and that of the Jews. ${ }^{\text {"2y }}$ Connor portrays Sobieski's political and civil attitudes toward his subjects using the same sort of characteristics and imagery that he uses to describe those rulers of past centuries who he deemed to be most honorable and generous.

As a noble, he not only seems to exhibit the traits of Zamoski but later becomes Zamoski by default with his marriage to the late general's widow. He is a statesman that embodies all that is great in Connor's Poland. Yet, Connor does not ignore the great general in Sobieski. Connor continues to give Sobieski the traits which Connor esteemed in Zamoski, Batori, the Wry-Mouth and Casimir Jagiello. Connor's Sobieski defies the Ottoman Empire in his wars to recover Podolia in the same way that Connor's Boleslaus the Wry-Mouth stands up to the Holy Roman Empire.

The Hero

Sobieski defeats the Ottomans during Michael's reign. Sobieski continues to counter the Ottoman invasion until 1676. Connor gives the reader examples of epic battles that precede the battle of Caminiec. In these pitched battles and heroic sieges, Sobieski beats back the Ottomans against all odds. ${ }^{311}$ The Ottomans attempt to take the

\footnotetext{
29 Connor. The History of Poland, 199.

30) Connor, The Ilistory of Poland, 170-171.
} 
fortress of Slotskow and Leopol. Although outnumbered Sobieski does not give in. Instead Sobieski stands and fights a combined army of Ottomans and Tatars. Like Zamoyski and Boleslaus he wins against all odds.

Connor emphasizes how Sobieski became the dreaded adversary of the Ottomans, the new Empire attempting to force despotism upon the Poles. Connor explains that at the siege of a fortress called Trembowla, the Ottomans fled after hearing the king of Poland was coming to relieve the fortress. The king becomes a major force in the war against the Ottoman army. Connor lets the reader know how “...the Terrour of King Sobieski's Name struck such a faintness into the Infidels, that they immediately dislodged their Cannon from their Batteries, which consisted of a hundered Pieces, and forthwith march'd towards Caminiec with a great deal of Confusion." ${ }^{31}$ Sobieski has bested his enemies and now keeps them on the run.

Connor's Sobieski is a great warrior toward the end of Letter IV, when the Ottoman empire's most feared adversary joins the Holy League. It is this decision that unites the Commonwealth with the Holy Roman Empire, the Pope and the Venetians to push the Ottoman Empire out of not only Poland, but Europe as well. According to the historian Norman Housley, this war against the Ottomans had many of the traits that were apparent in the Crusades. ${ }^{32}$ Thus, in Connor's text Sobieski becomes a part of a Crusade that elevates his status from a warrior to a religious knight.

\footnotetext{
${ }^{31}$ Connor. The History of Poland, 170-171.

32 Norman Housley. "The Crusading Movement." The Oxford History of the Crusades. Ed. Johathan RileySmith (New York: Oxford University Press, 2002), 289-290.
} 
Connor emphasizes Sobieski's part in the raising of the siege of Vienna. These pages are important for the way they rounds out Sobieski's character. Sobieski is not only a hero, a liberal ruler, a politician and a warrior, but now Sobieski becomes a pious Crusader. He is said to have entered Vienna as a hero. ${ }^{33}$

The Holy League manages to push back the Ottoman armies and raise the siege of Vienna in 1683. In a brash move Sobieski enters the city in a procession modeled after a Roman Triumph. Connor writes about how, "[t] he King made his Entry into Vienna, through the Breach, with great Acclamtions of the People, the great Turkish Standard being carr'd before him, which he afterwards sent to the Pope, and which I have seen hung up in the

Church at Loretto in Italy." ${ }^{34}$ Connor explains how Sobieski continues to aid in the war with the Ottomans. It is during Sobieski's time in the Holy League that Connor lets the reader know about the king's ability to lead the Poles to victory and how he was generous during the siege of Zytchin.

Connor ends the king's heroic tale with his discussion about Sobieski's greed. Connor lets the reader know that, like the rest of Poland's elites, Sobieski is becoming seduced by greed and despotism. Thus like his people, Sobieski is both the hero and defender of freedom but also enamored with personal wealth. It is with this growing issue in mind that Connor bids fairwell to his heroic statesman and discusses the last years of his daughter's life and the election of a German king to the throne of Poland. Connor mentions at the end of Letter IV that Sobieski “... for several Years lean'd towards the

${ }^{33}$ Connor. The History of Poland, 175-176.

34 Connor, The IIistory of Poland, 175 
French Interest. 'Tis certain, that at last he lov'd Money so well, that I heard the Poles themselves say That he was the most covetous and richest Prince that ever sway'd their Scepter." ${ }^{35}$ Even after becoming the hero and merciful king, a part of Sobieski still remains as greedy as a Vasa. This sad ending to Sobieski's life is dwarfed in comparison to the way Connor focuses on his heroics against the Ottomans and his liberal mentality toward politics. The importance of Sobieski's life lies in his ability to rise in status regardless of his low birth. Through his parents' planning and his own political abilities Sobieski was able to change his station in life from a member of the Sejm to the king of the Commonwealth Once in the throne he becomes a liberal thinker who promotes the modern philosophy and religious toleration.

\section{A "German" Elector On The Throne}

With the death of Sobieski, Connor introduces the reader to the newest king to take the throne. The new king Frederic Augustus of Saxony, or August II (1697-1704, 1709-1733) becomes the focus of the end of Letter IV. The history of Frederic's time on the throne is short and filled with anxiety. It is also incomplete due to Connor's decision to follow Sobieski's sister out of the kingdom to Bavaria where she was to marry the elector of Bavaria. Although Connor was already in the process of leaving Poland to look after Sobieski's sister, he did hear about the election through members of the Bavarian queen's retinue and family. Connor makes it a point to let the reader know "...that this is the first time the Poles have elected a German Prince, and likewise the first that they have excluded their King's Son; for from the Year 550, when this Monarchy began, to this present Election, the King's Children have been always chosen, and the Crown, tho

35 Connor, The History of Poland, 177. 
elective, has been in the same Family successively for above eight hundred Years." ${ }^{36}$ This situation made Connor anxious.

Connor feared that just as Batori's family were bypassed for the Vasa Dynasty, Sobieski's family was being pushed aside for another family that may have had questionable merit. This new dynasty was Saxon. August II was the ruler of Saxony and the elector of the Holy Roman Empire, one of the "despotic" powers constantly conspiring against the Commonwealth in Connor's history. Connor includes the election of August II in order to remind his English readers that the election of a "German" king or any member of an empire that in his opinion promotes despotism is a bad decision. Although England tended to envision France as its major antagonist, Connor may have had little faith in the new king, William of Orange. Connor worries about England's choice of king in the same way he worries about Poland's decision to elect a member of the Holy Roman Empire.

Connor still hopes that the new Saxon king may be a valid choice for the throne, but he is still bothered by the nobles' decision to forsake a Polish candidate for a subject of the Holy Roman Empire. Connor seems to believe the nobles were too greedy and jealous of each other to allow a Polish noble to take the throne. "But thereafter it is likely to prove otherwise, for the Gentry of Poland are so jealous of their own Kings, and so covetous to be enrich'd by foreign Princes, that probably henceforward they will choose no Native...." ${ }^{3^{\top}}$ He reminds the reader that the nobles fear native kings because some of these native kings were not worried about the Commonwealth. They squandered their

\footnotetext{
${ }^{36}$ Connor. The History of Poland, 209.

3- Connor, The IIistory of Poland, 209.
} 
time on the throne intriguing and invading other kingdoms "... so the Poles observing that their Native Kings have not of late sufficiently promoted the Interest of their Country, were wise enough to choose a Foreign Prince, whose Wealth and Courage would enlarge their Dominions...." ${ }^{38}$ To Connor it was the exact opposite. The native kings seemed more prepared to save the Commonwealth. This theme was especially evident in the chapters on Sobieski who did more to strengthen the Commonwealth than the three Vasas

Connor blames the Clergy and Pope for the new German king. He believed that the Pope wanted to use the throne of Poland to convert Protestant princes. Since the majority of the Catholic clergy in the Commonwealth had to follow the Church of Rome, they supported the pro-Saxon faction. Connor worries that “... if the Pope sees that the present King of Poland's Chidren are confirm'd in the Doctorines of the church of Rome, he will doubtless after his Death make the same Endeavours to advance to that Throne either the King of Sweden, the Elector of Brandenburg, or the Elector of Hanover, as he has done in favour of the Elector of Saxony...." ${ }^{34}$ He seems to portray a declining Poland with this image of the Polish throne. It is becoming a tool of the Pope rented by the nobles.

\section{Where Is Zamoski?}

As was the case with earlier dynasties, the power of the nobility and the religious figures of the time seem to be forces that propel the elections. The Germans once more attempt to put someone on the throne. In this election, however, there is no great noble to

${ }^{38}$ Connor. The History of Poland, 152.

39 Connor. The IIistory of Poland, 209-210. 
rise and counter the Habsburg candidate from the Holy Roman Empire. There is no Boleslaus the Wry-Mouth or Zamoski to force the "Germans" back. Sobieski's family are kept at bay by the nobles and excluded from the election. He has the same point of view as the modern historians Lukowski, Gierowski, Friedrich and Zamoyski's view of the Commonwealth's decline, Connor's tone gives the reader a feeling that the Poles are either about to go into decline or renewal. ${ }^{40}$

The election is described in a context that makes it appear to be less of an election and more of a negotiation. All of Poland's usual antagonists put their powers in back of specific candidates, "[f] or tho the Primate and many other considerable Persons did insist on the pretended Legality of their Election...."41 The Ottomans, Muscovites, French and Germans threaten to invade the Commonwealth if their candidate is not elected. Yet, before the Poles can hold a true election, “...the Elector of Saxony was actually Crown'd; he was in possession of the Metropolis Cracow, the strongest Town in Poland; that 8000 of his disciplin'd Troops were in the Kingdom; that the major part of the army had declared for him... they thought it more advisable to quit his Interest than to give occasion for Civil War..." ${ }^{42}$ While the nobles of the senate decide how to best hold the elections, the Poles in Cracow decide to force the election of the Saxon candidate, by giving him the keys to the city and the garrison to help bolster his own troops. This change in Commonwealth politics does not seem to bode well for the Commonwealth.

\footnotetext{
41 Connor, The History of Poland, 208-210 and Lukowki Liherty's Folly. 187-263. Gierowski. "The International Position of Poland in the Seventeenth Centuries," 236-238. Friedrich. The Other Prussia. 6067. and Zamoyski. The Polish Wav, 223-268.

41 Connor, The History of Poland, 207.

42 Connor. The History of Poland, 207-208.
} 
Connor admits that the Saxon king had money and connections in Europe that may help to strengthen the Commonwealth. ${ }^{43} \mathrm{He}$ concludes this chapter with the hope that this new king may be able to continue to sustain the Commonwealth. Connor hopes that his wealth and dynastic ties may help to propel Poland forward even though he is a "German." Letter IV leaves the reader with a feeling that, though the Poles hold their right to be important to their well being, they have become complacent. They are not willing to risk civil war for the election of a new king. Instead they find safety in an old maxim, “... That Kings were easy enough to be had without shedding Blood for any; and that they were easily depos'd if they usurp'd any greater Authority than the Laws allow'd And therefore they think it more prudent, after having sufficiently empty'd the Candidates Pockets, to declare for the first of them that joins his Party, and appears in Arms since he is deem'd qualifie'd, than to expose their Country to ruin and devistation...." ${ }^{\prime 4}$ The people of the Commonwealth are weary of war and political strain. The nobles begin to lean towards compliance with other nations and candidates rather than aggressive defense of the Commonwealth's political ideals. Connor fears that this compliance could be a cause for the Commonwealth's downfall. This fear of the Saxon king is fueled not only by fear for Poland's survival, but also the future of England.

Unlike Lukowski's vision of the rebellious nobility, Connor's problem with the nobles in the Commonwealth lies in the way these men refuse to put up a fight against the intrigues of outside forces. Connor feels that the Poles are becoming to complacent, “...

\footnotetext{
43 Connor. The History of Poland, 209-210.

${ }^{44}$ Connor. The IIistory of Poland, 208.
} 
by adhering to an illegal Election, of which the success is always doubtful: for by their Constitution no Election can be legally made without the universal Consent of the Lords and Commons of both States, Poland and Lithuania, assembl'd in Parliament." ${ }^{15}$ The Poles seem to have lost their old desire for a free government. To Connor the people of England have also allowed their kingdom to be ruled by an outsider from The Holy Roman Empire who may serve England well or convert it into a despotic government. Being of Irish origin and accused of being a Jacobite spy, Connor may have feared a trend toward strong central government with little if any tolerance for those ethnic groups that have not become Anglicized.

Connor dies in 1698 after the publication of his history. What he saw as a great free parliament lives another century before finally succumbing to Austria, Prussia and Russia. Armies from those places that Connor's heroes had not only repelled but brutally decimated in earlier centuries would divide the Commonwealth between them. He feared that the Commonwealth may be losing its political power. Yet, he was not ready to count it out of the political landscape. The Commonwealth was too strong and to large to imagine it faltering. Connor also believes the Commonwealth's history was too important not to write. To Connor Poland's rise and potential failure or success still helped to give England a model for analysis and copy.

Regardless of the Commonwealth's eventual fate, it represents another example of how a decentralized government can continue to be powerful while allowing freedom of religion and ethnic diversity. Connor does not blame any recent shortcomings on the

\footnotetext{
${ }^{45}$ Connor. The History of Poland, 207.
} 
strength of the government. As long as the government was supported by a Zamoski or a Bishop of Kovia and lead by a strong king that represented all that was great in the Piast or Jagiellonian eras, the Commonwealth could continue to be both free and strong. Rather, Connor blames any recent problems on the nobles' desire for peace, the Pope's need to convert Protestants, and the election of possible despotic influences. The strong history of Poland's liberty was the driving force that made Connor convert his notes into The History of Poland. The embodiment of this Commonwealth could be found in the character of a Sobieski. 
Chapter V. Conclusion

Bernard Connor's The History of Poland is far more complex than often portrayed in his biographies. He was a contemporary of King John III Sobieski. He not only visited the kingdom but worked as the king's family physician. Connor became a member of Sobieski's court. He spent time getting to know both the leaders in the senate and the history of the Commonwealth they helped govern. He used the skills he learned as a scientist to research the history of the Commonwealth and come up with his own theories. Connor began to compare England and Poland-Lithuania. Through his research and comparisons, he created The History of Poland. It was an attempt to not only chronicle the history of the Commonwealth but also to point out of how a decentralized government can continue to stay strong while giving the freedom to vote and veto to some section of the population.

His history was an attempt to give England a better understanding on how to rule over a multicultural kingdom. Connor hoped that the history could help a seventeenthcentury England which had suffered from a continual contest between the Stuart Dynasty which wanted control and a Parliament that excluded both the lower classes and many of the kingdom's ethnic minorities. By writing about a Polish-Lithuanian Commonwealth that is ruled tolerantly and defended by a heroic European people, Connor's history can be used to support Wolff's claims that the Enlightenment created Eastern Europe and deemed it backward. Connor's text portrays a forward thinking Poland that is not only part of one Europe, but politically important and already familiar to the people in the west of Europe. 
Wolff's focus on the Enlightenment philosophers and their creation of an Eastern Europe examines how the eighteenth-century philosophers created a land that was more fantasy than reality. It was largely based on the works of Voltaire, a philosopher who disdained Poland for the way the nobles elected their leaders and voted on issues of state. Voltaire believed Poland was relegated to an "... anthropologically... lower level of civilization."1 Wolff emphasizes Voltaire's desire to focus on the exploits of King Charles XII and the Tsar Peter III (1761-1762) and Tsarina Catherine II (1763-1796). If Wolff is correct in his argument that Voltaire and other Enlightenment philosophers wished to support the creation of despotic power in the east of Europe in the same way that rulers in the west governed their kingdoms, then the Polish-Lithuanian Commonwealth was as much a victim of changing political ideologies as they were of political stagnation. According to Wolff "Voltaire's fantasies of conquest in Eastern Europe focused serially on a Swedish king, a Russian tsar, and a German princess."2 This image of the fantastic and primitive seems to be included in Connor's biographies.

In biographies such as Baruch S. and Jean L. Blumberg's "Bernard Connor (1666-1698): and His Contribution to the Pathology of Ankylosing Sodalities," and Davis Coakley Irish Masters of Medicine the sections on Poland are summarized and tend to highlight the differences between the Polish-Lithuanian Commonwealth and "western" Europe. Connor's views on Poland are often misrepresented by excerpts from his writing that are quoted out of context.

\footnotetext{
1 Wolff. Inventing Eastern Europe, 91.

2 Wolff. Inventing Eastern Europe, 362.
} 
Connor uses vocabulary that, if misrepresented, makes the Commonwealth seem alien to the rest of Europe. Connor's use of "different" and "unique," however, are an attempt to emphasize certain things within Polish culture or politics that made it a distinct culture. Often these specific word choices are followed by other descriptions and words that make these differences better than some other sections of Europe. For instance, Connor describes their clothes as more "manly" and their government as more "republican." These words are not used to separate the Commonwealth from the rest of Europe. They are always included in the European context. In his preface he begins to lay out the major points of his argument not only referring to Poland as a part of Europe, but also comparing it to England. He lets the reader know the reasons for his history. Connor wanted to discuss a kingdom that "... is in some respects like that of ours [England]" and the "... satisfy the Curiosity who long'd to see some Account of that kingdom [Poland] ...."4 Neither reason portrays Poland as primitive or alien to Europe.

Connor's first contact with Poles and the Commonwealth was in France when he befriended the Chancellor of Poland and his sons. His meeting with the Chancellor's sons was the catalyst behind his journey to the Commonwealth. Throughout his letters he refers to English speakers who worked in some fashion either in European politics or the Polish-Lithuanian government. Connor begins to gain an insight into the Commonwealth once he attaches himself to Sobieski's court. As a member of a high-ranking Irish family he identified with the Commonwealth's system of government. Although he realized the plight of the serfs and Cossacks, he was willing to forgive the Commonwealth for its

\footnotetext{
${ }^{3}$ Connor. The History of Poland, 101 and 153-154.

${ }^{4}$ Connor. The IIistory of Poland, iii-iv.
} 
shortcomings in the face of the nobilities' ability to share power with each other regardless of their background. He was also amazed at the way the Commonwealth was able to elect its kings. This semi-democratic government was important to an English subject of Irish origin who spent most of his life watching the struggle between the kings and the parliament. Poland-Lithuania seemed progressive in its implementation of the powerful senate that kept the king at bay. Connor voices this opinion best when he mentions the young noble, Duke Radizvill, who had not only visited England but gave a negative critique of the Stuart monarchy.

Connor makes Sobieski the embodiment of both the heroic statesman and a free thinking king. He gave Sobieski all of the positive characteristics of the heroic nobles, clergy and kings within his history. Connor also gives Sobieski some of qualities that are similar to the bad rulers of the Commonwealth, but these traits are eventually overcome as he becomes the heroic king and statesman of his later years that Connor portrays. The rise of Sobieski from lower gentry to king demonstrates both the greatness of Connor's former master and the freedom of mobility within the Commonwealth. As a king, Sobieski becomes the liberal and open-minded ruler that Connor wished England had. Connor includes a debate with a Jesuit over the nature of life and the soul in order to show Sobieski's ability to reason and his tendency to nurture a forward-thinking society.

Connor knew that England's Parliament was neither truly representative nor as powerful as the king. He knew that the Stuarts were at times ambivalent towards Catholic factions within their kingdom and antagonistic towards Protestant factions who 
disapproved of their rule. Cromwell continued to colonize Ireland and rule over the kingdom with a despotic attitude in $1698 .^{5}$ The English Parliament would have to continually stand strong against the intrigues of the Stuart Dynasty and the intolerant rule of Cromwell. However, the English Parliament also had little issue with banning certain religious factions from government. They also continued to push for Protestant colonization within Ireland and Scotland.

The gentry's control of the Polish parliament was not that offensive to the young author. What Connor focuses on in his book is the way Parliament drove the Commonwealth and elected the kings. According to Connor, the Polish throne was elective since the beginning of their kingdom. Through Sobieski Connor emphasizes the possibility for any member of gentry to rise to the senate and the throne. The Protestants may often be portrayed as troublemakers, yet they are nevertheless allowed to be a part of the senate. In the chapter on Sobieski, Connor mentions the oath to continue religious freedom. Like the Polish kings before him, Sobieski was forced to swear to defend the religious freedoms of the Commonwealth. This action again reinforces Connor's characterization of the Commonwealth.

Connor's chapters on Sobieski seem to epitomize the free parliamentary system and the rights of the various ethnic and religious factions within. Connor makes a point to emphasize that Sobieski was of lower gentry. He made his political climb by being a clever politician and serving in the military. Sobieski's political antagonist, Patz, attacked him through a constitutional basis, and Sobieski helped his power base through the use of constitutional arguments. Sobieski attempted to keep control of the throne through

\footnotetext{
5 Lehmberg. The Peoples of the British Isles, 192.
} 
returning many of the freedoms lost under the Vasa Dynasty. Connor's chapters on Sobieski depict a Commonwealth that was entrenched in parliamentary ideologies. Connor praises Sobieski for his ability to protect religious and intellectual freedoms.

Connor makes a point to discuss the errors and intrigues within Polish history including the Piast civil war, senatorial back stabbing, serfdom, and the badly-managed attempt to suppress the Ukraine. To Connor these issues were not solely a Polish problem but a problem within the structure of a seventeenth-century constitutional monarchies. His description of Polish-Lithuanian serfdom was relegated to a few paragraphs. $\mathrm{He}$ spends more time on the problems with the Ukraine and the reasons for the Cossack rebellion. Even these negatives are not without comparisons to England. Although the Commonwealth is attacked by several kingdoms including Transylvanian, Sweden and the Ukrainian, the majority of Connor's The History of Poland focuses on the government and its ability to withstand the intrigues by the rulers of France, Russia and the Holy Roman Empire

Although Connor spent several years studying and teaching in France, he seems to disapprove of French intrigues within Poland and their support of the Jesuits. Connor demonstrates a bias toward Poland and England. He sees the rulers of France, the Holy Roman Empire and the Ottoman Empire as despotic and, therefore, bad. He does not see a difference between The Holy Roman Empire and their leaders. To Connor the both the people and rulers of The Holy Roman Empire were "Germans." Connor tends to use specific religions of the Empire only when giving titles for possible Polish kings. The rulers of The Holy Roman Empire, like those of the French and Ottomans, are tyrants attempting to ruin the freedom within the Polish kingdom. Unlike Enlightened 
philosophers like Voltaire, Connor saw these growing despotic powers as the greater threat to Europe. He did not see the value of a central authority and valued any government that seemed to be decentralized. Connor died in 1698 after publishing The History of Poland. He would have thought that the creation of a central authority was despotism and counter to everything that so many members of the Commonwealth fought so hard for. To Connor a strong king was one step closer to despotism and a step backward.

Connor's history is a political and cultural morality play that used the seventeenth-century Polish-Lithuanian Commonwealth in order to push the cause of a strong but constitutional government. Connor's view of Poland's ability to portray strength, while adhering to a multi-cultural and constitutional monarchy, makes it a perfect foil to the all-powerful monarchy of France. Poland was the land where kings were elected and overthrown at will. The gentry allowed all races and religions into the senate. To Connor it was not just a powerful Commonwealth, it was the continental England.

Connor died in England after suffering three disgraces based on ethnic, political and religious issues. He knew what it was like to be alienated by his own government due to religious and ethnic affiliation. He hoped that his book might shed light on Poland and educate the English upper class in the proper method of rule. Through his untimely death, he was spared the sight of Poland's decline. He did not have the ability to question Poland's three partitions. He never had the ability to enter into the dialogue of the eighteenth-century authors of the Enlightenment. He did not have the chance to debate with the Enlightenment critics of the Commonwealth. 
It is possible to combine both Larry Wolff's theory about the Enlightenment's creation of an "eastern" Europe and the Polish historians' view of the Prussian need to forget Poland. The Prussian and Russian historians of the eighteenth century would have belonged to the Enlightenment. As Wolff mentioned, the Enlightenment historians and philosophers wanted to turn Poland and other Europeans into backward lands with outdated political standards. In the time of the "Enlightened Despot" it was necessary to foster an image of the Commonwealth.

Connor's prestige as a scientist shows that he was a forward-thinking individual. It also shows that he was not a foolish man. His desire to give the English an example of the Commonwealth they needed also helps to undermine the theory that Poland was becoming backward. Lukowski, Zamoyski, Davies and Stone all mention that the Commonwealth was attempting to correct political errors within the government when the partitioning powers divided it up. ${ }^{6}$ Yet, even these changes fostered some form of parliamentary government. Stanislaw Auguest Poniatowski, who reigned from 17641795, attempted to create a constitutional monarchy. While Poniatowski tried to find a middle ground between parliament and the king, several powerful nobles were reorganize the senate and forging a constitution. This attempt to write a constitution and create a Polish version of the House of Lords would lead to the Great Sejm which of 1788-1792.

The Commonwealth became backward due to pressure from outside the kingdom and the changing political tastes. The Commonwealth began to suffer when Europe began

Lukowski. Liherty's Folly, 186-263, Zamoyski, The Polish Way, 223-258, Davies 511-546 and Stone. The Polish-Lithuanian State, 268-287.

Stone. The Polish-Lithuanian State, 322-323. 
to see certain forms of despotic power as the best form of government. Although the Enlightenment did not invent despotism, it did help to make certain forms of despotism seem more advanced in comparison to those kingdoms without a strong central authority. In the quest for the perfect government, some western European philosophers of the Enlightenment began to push for specific forms of central authority. The kingdoms in the west of Europe began to push for a form of despot that had an enlightened view of government and chose to be an open-minded ruler. Poland became primitive because it was still trying to form a parliamentary government with a limited monarchy. England was one of the other European kingdoms that never allowed despotic forms of government to take permanent control over their kingdom. England was able to move past the seventeenth century struggles between king and parliament without allowing despotic rule. It is therefore no surprise that Connor saw England within Poland. Both kingdoms continued to support some form of parliamentary government throughout the seventeenth centuries. Perhaps if the political atmosphere had been different, the PolishLithuanian Commonwealth may have been able to stabilize itself in the same way that England had done after the seventeenth century.

In a time when many twenty-first century countries are supporting some form of coalition, union or republic, the Commonwealth could be said to have had the seeds of modern politics but just never had the chance to grow. The idea of a backward and primitive Poland seems to have been formed by those eighteenth-century authors and rulers who believe despotic government was the best form of real government

The value of Connor"s The History of Poland is the way its "western" European writer holds the Commonwealth up as a model government for at least one member of the 
Atlantic powers to mimic. Connor's use of Poland-Lithuania as a model government helps the theories of Larry Wolff and Maria Todorova. Both accept the theory that eastern Europe was created by western Europe in an attempt to make western Europeans superior in their political and philosophic ideologies. Connor shows that at the turn of the eighteenth-century Poland was still not only part of a united Europe but a powerful and important political and cultural trailblazer. Poland became unimportant in hindsight. Connor demonstrates that Poland was of importance both in the European context of political interaction and as an example of a parliamentary government throughout the seventeenth century.

Europe in the modern era is once again redefining itself. It is time to reexamine the parliamentary-driven Commonwealth that Connor so adored. There may be more to it than the mythical backward land created by Enlightenment thinkers. 
Primary Sources:

\section{LIST OF REFERENCES}

Chevaliers, Pierre. A Discourse of the Original, Country, Manners Original, Country, Manners, and Government of the Cossacks. With Another of the Precopian Tartars And the History of the Wars of the Cossacks Against Poland. London: Printed by T. N.. 1672.

Collins, Richard. The Cause of England's Misery. London: E. P., 1698.

Connor, Bernard . A Copy of a Letter Sent His Grace *** From Dr. Connor, Member of the College of Physicians and Royal-Society, Concerning His Medicina Arcana de Mystico Corporis Mumani Statie: or A Latin Treatise, In Which He Designs to Explain the Miracles Relating to Human Bodies, by the Prinicples of Physice. London: For Sam Briscoe, 1696.

The History of Poland: in several letters to persons of quality, giving an account of the antient and present state of the kingdom, historical, geographical, physical, political and ecclesiastical...: with sculptures, and a new' map after the best geographers: with several letters relating to physick. vol. 1. Editor John Savage. London: Printed by J.D, 1698.

Coxe, Sir Richard. Aphorisms Relating to the Kingdoms of Ireland. London: For Joseph Watts, 1689

Eleazer, Gilbert. Newes from Poland. London: Printed for Nathanael Butter, 1641.

Hayley, William. A Sermon Preached At The Funeral of Doctor Connor. London: For Jacob Tonson, 1699.

Johnson, Samuel Johnson, Remarks Upon Dr. Sherlock's Book Intitled, The Case of the Allegiance Due To Soveraign Princes, Stated and Resolved, etc. Second Edition. London: Printed for J. Humphries, 1690.

N. N, An Accoumt of The Defeat of Count Teckely and His Being Slain: Together With a Total Rout, Given to the Turkish Army by the United Forces of the Christian Emperour and the King of Poland. London: Printed by E. Mallet, 1683.

[Attributed to Savage, John.] The Ancient and Present State of Poland, Giving A Short, But Exact, Account of the Scituation of Ihat ('ountry, The Manners and Customs of the Inabitants, The Several, Successions of Their Kings, Their Religion, etc., Drawn Out of Their Best Historians: To Which is Added, An Imperial Account of The Death of The Late King, and Of The Present Election, As It Now Stands. London: Printed for E. Whitlock, 1697.

Sobieski, John. Polish Mamuscripts, or the Secret History of the Reign of John Sobieski, to the III. London: Printed for T.N., 1683. 
Voltaire. Letters Concerning the English Nation. Edito rand Translator Nicholas Cronk. New York: Oxford University Press, 1994. Reprint, New York: Oxford University Press, 1999.

Lion of the North: Charles XII of Sweden. Translator M.F. O. Jenkins. New York: Associated University Presses, 1981.

Secondary Sources:

Blumberg, Baruch S. and Jean L. Blumberg, "Bernard Connor (1666-1698): and His Contribution to the Pathology of Ankylosing Sodalities," Journal of the History of Medicine and Allied Sciences. vol. 13. New York: H. Shuman, 1958. 349-366.

Coakley, Davis. Irish Masters of Medicine. Dublin: Town House, 1992.

Davis, Norman. Europe: A History. New York: Oxford University Press, 1996.

God's Playground: A History of Poland in Two Volumes, Volume I: The Origins to 1795. New York: Columbia University Press, 1982.

The Isles: A History. New York: Oxford University Press, 1999.

English Short Title Catalogue Project. Early Printed

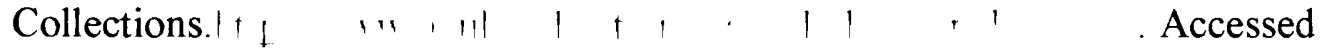

June 10, 2003. The British Library London: United Kingdom, 2003.

Friedrich, Karin. The Other Prussia: Royal Prussia, Poland and Liberty, 1569-1772. New York: Cambridge University Press, 2000.

Gierowski, Jozef Andrzej. "The International Position of Poland in the Seventeenth Centuries," A Republic of Nobles: Studies in Polish History to 1864. New York: Cambridge University Press, 1982. 218-238.

Halecki, Oscar. "Problems of Polish Historiography," Slavic and Eastern Review: American Series. vol. 2, Issue I. March, 1943. 223-239.

Housley, Norman. "The Crusading Movement," The Oxford History of the Crusades. Editor Johathan Riley-Smith. New York: Oxford University Press, 1999. Reprint, New York: Oxford University Press, 2002. 258-291.

Kriegel, Lara. "The Pudding and the Palace: Labor, Print Culture, and Imperial Britain in 1851," After the Imperial Turn: Thinking with and through the Nation. Editor Antoinette Burton. Durham: Duke University Press, 2003. 230-245. 
Lehmberg, Stanford E. The Peoples of the British Isles: A New History, From Prehistoric Time to 1688. vol. I. California: Wadsworth Publishing Company, 1992.

Lukowski, Jerzy. Liherty's Folly: The Polish-Lithuanian Commonwealth in the Eighteenth Century, 1697-1795. New York: Routledge, 1991.

Pollard, A. E. The Jesuits in Poland: The Lothian Essay, 1892. New York: Haskel House Publishers Ltd., 1892. Reprint, New York: Haskel House Publishers Ltd., 1971.

Porter, Brian. When Nationalism Began to Hate: Imagining Modern Politics in Nineteenth-Century Poland. New York: Oxford University Press, 2000.

Reddaway, W. F. J. H., Penson, O. Halecki, and R. Dyboski. The Cambridge History of Poland: From the Origins to Sobieski (1o 1696). London: Cambridge University Pres, 1950. Reprint. New York: Octagon Books, 1971.

Said, Edward. Orientalism. New York: Vintage Books, 1978. Reprint, New York: Vintage Books, 1979.

Stone, Daniel. The Polish-Lithuanian State, 1386-1795. Seattle: University of Washington Press, 2001.

Tazbir, Janusz. "The Fate of Polish Protestantism in the Seventeenth Century," $A$ Republic of Nobles: Studies in Polish History to 1864. New York: Cambridge University Press, 1982. 199-217.

Todorova, Maria. Imagining the Balkans. New York: Oxford University Press, 1997.

Webb, Alfred. A Compendium of Irish Biography: Comprising Sketches of Distinguished Irishmen, and of Eminent Persons Connected with Ireland by Office or by Their Writings. First. Edition. New York: Lemma Publishing Corporation, 1878.

Whelan, Kevin The Tree of Liberty: Radicalism, Catholicism and the Construction of Irish Identity, 1760-1830. Ireland: Cork University Press, 1996.

Wolff, Larry. Inventing Eastern Europe: The Mapping of Civilization on the Mind of the Enlightenment. Stanford: Stanford University Press, 1994.

Zamoyski, Adam. The Polish Way: A Thousand-Year History of the Poles and Their Culture. London: John Murray Publishers, 1987. Reprint, London: John Murray Publishers, 1999 